Scholarship Repository

University of Minnesota Law School

Articles

Faculty Scholarship

1992

\title{
The Forty-Third Session of the UN Sub-Commission on Prevention of Discrimination and Protection of Minorities: The Sub- Commission Under Scrutiny
}

\author{
Karen Reierson \\ David Weissbrodt \\ University of Minnesota Law School, weiss001@umn.edu
}

Follow this and additional works at: https://scholarship.law.umn.edu/faculty_articles

Part of the Law Commons

\section{Recommended Citation}

Karen Reierson and David Weissbrodt, The Forty-Third Session of the UN Sub-Commission on Prevention of Discrimination and Protection of Minorities: The Sub-Commission Under Scrutiny, 14 HUM. RTS. Q. 232 (1992), available at https://scholarship.law.umn.edu/faculty_articles/404.

This Article is brought to you for free and open access by the University of Minnesota Law School. It has been accepted for inclusion in the Faculty Scholarship collection by an authorized administrator of the Scholarship Repository. For more information, please contact lenzx009@umn.edu. 


\section{The Forty-Third Session of The UN Sub-Commission on Prevention of Discrimination and Protection of Minorities: The Sub-Commission Under Scrutiny}

Karen Reierson and David Weissbrodt

I. INTRODUCTION

II. COUNTRY SITUATIONS

A. Baltics

B. Cambodia

C. East Timor

D. El Salvador

E. Guatemala

F. Iran

G. Iraq and Kuwait

H. Israeli-Occupied Territories

I. Somalia

J. South Africa

K. Tibet

L. Confidential 1503 Procedure

III. STUDIES AND REPORTS
A. Completed Studies

B. Apartheid in South Africa and Racism Throughout the World

C. Minorities

D. Freedom of Expression

E. Human Rights and the Environment

F. Administration of Justice

G. Economic, Social, and Cultural Rights

H. Other Reports 
IV. PRE-SESSIONAL WORKING GROUPS 266

A. Working Group on Indigenous Populations 267

B. Working Group on Contemporary Forms of Slavery 269

V. REFORM OF THE SUB-COMMISSION'S WORK 270

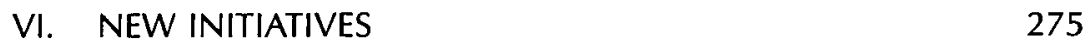

$\begin{array}{ll}\text { VII. CONCLUSIONS } & 277\end{array}$

\section{INTRODUCTION}

The twenty-six members of the UN Sub-Commission on Prevention of Discrimination and Protection of Minorities (hereinafter Sub-Commission) convened for the Sub-Commission's forty-third session during 6-29 August 1991 in Geneva. ${ }^{1}$ The Sub-Commission conducted its 1991 session in an atmosphere of self-examination, prompted by increasing criticism of its methods of work by its parent body, the Commission on Human Rights (hereinafter Commission). ${ }^{2}$ Once again the Sub-Commission confronted an overburdened agenda and was unable to consider all of the items scheduled for discussion. Yet, although they acknowledged the need for reform, Sub-Commission members were unable to reach a consensus on what steps they should take to alleviate the problems. Moreover, members disagreed about

1. The official report of the forty-third session is found in U.N. Doc. E/CN.4/Sub.2/1991/65 (1991) [hereinafter 1991 Report]. The United Nations Economic and Social Council (ECOSOC) established the Sub-Commission in 1947 to study issues related to discrimination and protection of minorities. The Sub-Commission is an expert body of twentysix members who serve in their individual capacity. Members are elected to four-year terms by the Commission on Human Rights. Like other UN subsidiary bodies, the composition of the Sub-Commission reflects a geographical balance that is maintained by allocating seats on the basis of five regional groups: Africa, Asia, Eastern Europe, Latin America, and West European and Other. This article is adapted from one which appeared in 8 AIUSA Legal Support Network Newsletter 31 (1991). For other analyses of the 1991 session, see generally Macpherson, Fetter, \& Patel, United Nations Sub-Commission on Prevention of Discrimination and Protection of Minorities, Forty-Third Session, Quaker United Nations Office (1991); Zoller, Consolidation of the Sub-Commission: Analytical Report of the 43rd Session of the Sub-Commission, 14 Hum. Rts. Monitor 3 (1991); 17 Human Rights Advocates Newsletter 1 (1991). The authors wish to thank Reed Brody of the International Commission of Jurists for sharing with us a draft of his forthcoming article on the 1991 Sub-Commission session, UN Sub-Commission on Prevention of Discrimination and Protection of Minorities, Forty-Third Session (1991), __ IC) Review (1992). For analyses of previous sessions of the Sub-Commission, see generally Brody, Convery, \& Weissbrodt, The 42nd Session of the Sub-Commission on Prevention of Discrimination and Protection of Minorities, 13 Hum. Rts. Q. 260 (1991); Maher \& Weissbrodt, The 41 st Session of the U.N. Sub-Commission on Prevention of Discrimination and Protection of Minorities, 12 Hum. Rts. Q. 290 (1990); Brennan, Brody, \& Weissbrodt, The 40th Session of the U.N. Sub-Commission on Prevention of Discrimination and Protection of Minorities, 11 Hum. Rts. Q. 295 (1989); Rosen \& Weissbrodt, The 39th Session of the U.N. Sub-Commission on Prevention of Discrimination and Protection of Minorities, 10 Hum. Rts. Q. 487 (1988). For other articles on the Sub-Commission, see Maher \& Weissbrodt, supra, at 290.

2. See infra notes 161-74 and accompanying text. 
which human rights concerns should receive priority. For example, some members believed that their normative work on civil and political rights is largely complete, so that more time should be spent on economic, social, and cultural rights; other members still wanted to focus on civil and political rights as the core of human rights protections-the guarantors of all other rights. Despite the efforts of the Sub-Commission chairman and the considerable discussion of methods of work, the Sub-Commission in 1991 failed to devise a specific plan of action for reform.

The lack of consensus about the Sub-Commission's proper role in promoting and protecting human rights-particularly where a major world power is involved - was spotlighted in its response to an attempted coup in the Soviet Union, which took place midway through the Sub-Commission's August 1991 session. The debate over whether or how to respond echoed the discussion at the 1990 session concerning the proper Sub-Commission response to urgent situations - most notably, at that time, Iraq's invasion of Kuwait. ${ }^{3}$ Once again some members stated that the Sub-Commission would lose credibility as a human rights body if it failed to address this urgent human rights situation at the center of world attention. Other members countered that there was as yet insufficient information for the Sub-Commission to act, or that the Sub-Commission should defer to higher-level UN bodies that were already in contact with the parties involved in the attempted coup.

Several experts were hesitant to take any action that might appear politically motivated, yet the lack of action also reflected political considerations. Tian Jin, the Sub-Commission member from the People's Republic of China, argued that the events were a purely internal matter of the Soviet Union which the Sub-Commission should not discuss at all. Miguel Alfonso Martinez (Cuba) asserted that the Sub-Commission would exceed its mandate if it made a judgment that the state of emergency proclaimed by the coup leaders in the Soviet Union violated either Soviet or international law. Martinez stated that the Soviet people should handle the situation themselves. Rajindar Sachar (India) responded that the state of emergency itself prevented the Soviet people from handling the situation themselves. Most members asserted that human rights questions were a matter of international concern, but they were reluctant to make any statement until more facts were known. In the end, the coup ran its course and collapsed without the Sub-Commission having taken any action other than the routine inquiry made by Leonardo Despouy (Argentina) as the Special Rapporteur on States of Emergency whenever a state of emergency is decreed.

Despite the lack of substantial progress on the reform issue, the SubCommission did move forward on other fronts. The Sub-Commission adopted

3. See Brody, Convery, \& Weissbrodt, supra note 1, at 264. 
for the first time a resolution concerning the human rights situation in Tibet. The Sub-Commission also focused on new aspects of economic, social, and cultural rights, such as forced evictions, the right to adequate housing, and fraudulent enrichment of government officials. In addition, the Sub-Commission adopted a resolution asking its $U N$ parent bodies to request an advisory opinion from the International Court of Justice concerning Israeli settlements in the occupied Arab territories.

This article discusses the accomplishments of the forty-third session of the Sub-Commission, including resolutions regarding human rights violations in specific countries, studies on various human rights issues, pre-sessional working groups on contemporary forms of slavery and on indigenous peoples, reform of the Sub-Commission's work, and new initiatives.

\section{COUNTRY SITUATIONS}

The Sub-Commission employs two procedures, one public and the other confidential, to examine the human rights situation in a specific country. On the one hand, ECOSOC resolution $1235^{4}$ authorizes the Sub-Commission to establish an agenda item for public discussion of alleged violations of human rights in specific countries. Nongovernmental organizations, governments, and Sub-Commission members may speak under the public agenda item, and the Sub-Commission may then adopt resolutions on the human rights situation in a given country. On the other hand, ECOSOC resolution $1503^{5}$ authorizes a confidential procedure whereby the Sub-Commission members meet in private to consider communications alleging consistent patterns of gross violations of human rights in particular countries. The Sub-Commission then confidentially refers to the Commission the country situations that merit further consideration. ${ }^{6}$

The Sub-Commission conducts its public examination of the human rights situation in specific countries under its agenda item on the "question of the violation of human rights and fundamental freedoms." In 1991 it adopted resolutions on the following nine countries or territories: Cambodia,

4. ECOSOC Res. 1235 (XLII), U.N. ESCOR, 42nd Sess., Supp. No.1, at 17, U.N. Doc. E/ 4393 (1967).

5. ECOSOC Res. 1503 (XLVIII), U.N. ESCOR, 48th Sess., Supp. No.1A, at 8, U.N. Doc. E/ 4832/Add.1 (1970).

6. See infra notes 53-55 and accompanying text for a discussion of the countries considered under the 1503 procedure at the 1991 session.

7. The full name of agenda item 6 is "Question of the violation of human rights and fundamental freedoms, including policies of racial discrimination and segregation and of apartheid, in all countries, with particular reference to colonial and other dependent countries and territories: report of the Sub-Commission established under Commission on Human Rights resolution 8 (XXIII)." 
El Salvador, Guatemala, Iran, Iraq, the Israeli-occupied Arab territories, Kuwait, South Africa, and Tibet. In addition, the Sub-Commission adopted two resolutions, under different agenda items, regarding humanitarian concerns - as opposed to human rights violations - in Somalia and Iraq, and one resolution requesting an advisory opinion of the International Court of Justice concerning Israeli settlements in the occupied territories. A draft resolution on the Baltic republics was withdrawn in light of the unsuccessful coup attempt in the Soviet Union and the declaration of independence by the Baltic republics during the session. The Sub-Commission's handling of the Baltics issue and its response to the attempted coup illustrate the lack of consensus among Sub-Commission members about how to respond to breaking events. In addition, the chairman of the Sub-Commission read a statement, which was accepted by the Indonesian government, on the human rights situation in East Timor.

The voting on country-specific resolutions began with a contentious discussion about the secret ballot procedure. ${ }^{8}$ Miguel Alfonso Martinez (Cuba) insisted that, under the applicable rules, either all or none of the country-specific resolutions had to be voted on by secret ballot. Chairman Louis Joinet (France) pointed out that Rule 57 permits resolutions to be adopted by consensus or, if a member requests, to be the subject of a vote. ${ }^{9}$ Martinez then declared that he was requesting a secret ballot vote on every country-specific resolution presented under this agenda item. Martinez's efforts angered some Sub-Commission members, particularly members from African countries, who felt that the action would make it impossible to adopt by consensus the annual resolution on apartheid in South Africa.

\section{A. Baltics}

A draft resolution on the Baltic republics (Estonia, Latvia, and Lithuania) ${ }^{10}$ by William Treat (United States) failed to gain support early in the session

8. The validity of the use of a secret ballot itself was not at issue. In 1989 and 1990 the Sub-Commission suspended Rule 59, which provides for open voting when voting on country-specific resolutions. The Sub-Commission took this step in order to increase the independence of Sub-Commission members and insulate them from government pressure. In 1991 the Sub-Commission's parent bodies - the Commission and ECOSOC-formally approved the secret ballot procedure. CHR Res. 1991/81, ESCOR, Supp. No.2, at 182, U.N. Doc. E/CN.4/1991/91 (1991); ECOSOC Res. 1991/31, at 67, U.N. Doc. E/1991/ INF/5 (1991). See Rule 59, Rules of Procedure of the Functional Commissions of the Economic and Social Council, at 14, U.N. Doc. E/5975/Rev.1 (1983). See Brody, Convery, \& Weissbrodt, supra note 1 , at 265-67.

9. Rule 57 reads as follows: "A proposal or motion before the commission for decision shall be voted upon if any member so requests. When no member requests a vote, the commission may adopt proposals or motions without a vote." Rules of Procedure of the Functional Commisions of the Economic and Social Council, at 14, U.N. Doc. E/5975/ Rev. 1 (1983).

10. U.N. Doc. E/CN.4/Sub.2/1991/L.21, 1991 Report, supra note 1, at 113 . At least one NGO 
and was eventually withdrawn amid general disagreement among Sub-Commission members concerning the proper response to unfolding events in the Soviet Union. The proposed draft noted "recent destabilizing political events" in the Soviet Union and expressed concern about violations of human rights in the Baltic republics during 1991. It also reiterated a Commission request that the Soviet Union investigate the violations and report the results to the Commission chairman. The initial effort to draft a resolution focused on both the general issue of self-determination for the republics and specific human rights violations that occurred in 1991." The violations included attacks by Soviet troops against unarmed demonstrators and attacks on customs posts. Because the Sub-Commission, unlike the Commission, does not have an agenda item on self-determination, and because the issue is so volatile, however, it was decided that the resolution should focus only on specific human rights violations.

Treat hoped to persuade other members that the resolution was a logical follow-up to a statement accepted by the Soviet government and read by the chairman of the Commission at its 1991 session. ${ }^{12}$ The statement, delivered on 26 February 1991, expressed grave concern over "recent tragic acts of violence involving violations of human rights" in Latvia and Lithuania, ${ }^{13}$ noted the "readiness of the Government of the Soviet Union to

advocated including Moldavia, Armenia, and perhaps other Soviet republics in any resolution on the Soviet Union. Others thought, however, that a resolution more narrowly focused on the Baltic republics would stand a stronger chance of gaining support at the Sub-Commission. A number of governments have never formally recognized the forcible 1940 incorporation of Estonia, Latvia, and Lithuania into the Soviet Union, but have not contested the incorporation of other territories into the Soviet Union following the Second World War. The Soviet Union itself has condemned the 1939 secret protocol between Nazi Germany and itself that led to the invasion and occupation of the three Baltic republics in the following year.

11. On 13 January 1991, Soviet troops attacked a television tower in Vilnius, Lithuania, leaving sixteen people dead and hundreds wounded. During that attack, Soviet tanks crushed people and cars; soldiers shot into a crowd of unarmed civilians gathered in front of the building. Several days later, on 20 January, Soviet troops attacked and occupied the Interior Ministry building in Riga, Latvia. Five people were killed and ten wounded. The perpetrators of the attacks were identified as special forces, known as "black berets" or "OMON" units, organized under the Soviet Interior Ministry. Following the January attacks, OMON troops continued to commit acts of violence. They detained, beat, and shot individuals as well as attacked more than thirty customs posts in Estonia, Latvia, and Lithuania. During the latest customs post attack, which occurred on 31 July 1991, just days before the Sub-Commission session and two weeks before the unsuccessful coup in Moscow, eight Lithuanian policemen and customs officers were shot, killing six and severely wounding two. Although there were no witnesses, the manner of the attack suggested that it was committed by professionally trained forces. The elite "OMON" units were reportedly disbanded following the failed coup in Moscow on 18-21 August 1991. See USSR: Continuing Violence in the Baltics, Helsinki Watch Bulletin, 19 June 1991; 6 Officials Slain at Border in Lithuania, International Herald Tribune, 1 August 1991, at 3, col. 1.

12. ESCOR, Supp. No.2, at 199, U.N. Doc. E/CN.4/1991/91 (1991).

13. This statement refers to the events of 13 and 20 January 1991, described in note 11 , supra. 
communicate without delay to the Chairman of the Commission the results of [its] investigation," and further noted "unresolved problems in the field of human rights in Lithuania and Latvia." ${ }^{14}$ Despite this precedent for action and the Soviet Union's failure to report results of any investigation to the Commission chairman, ${ }^{15}$ Treat was able to enlist only John Merrills (alternate, United Kingdom) to co-sponsor the resolution. Some members expressed privately their apprehensions that any criticism of the Soviet Union would further weaken President Mikhail Gorbachev's position against challenges from hard-liners in the Soviet Union, and might adversely affect the upcoming signing of a new all-union treaty designed to grant greater powers to the individual republics. Treat was also told that he should not table any resolution, because Gorbachev was in the process of conducting negotiations on independence for the Baltic republics.

The context of such discussions on the Baltics changed completely upon news of the coup in Moscow. As the Sub-Commission publicly debated how to respond to events, Treat mentioned that the Baltic states appeared to have been singled out for particularly repressive treatment and that he was now going to table the resolution on the Baltics that he had previously held back due to the concerns expressed by other Sub-Commission members. ${ }^{16}$ The coup failed within days, however, and Estonia and Latvia declared their independence (joining Lithuania, which had declared its independence in 1990). Consequently, a majority of Sub-Commission members thought that a resolution was no longer necessary.

On 23 August, two days after the coup leaders were arrested, Treat formally withdrew his draft resolution and announced that it would be replaced by a consensus statement addressing the general post-coup situation in the Soviet Union to be read by Chairman Joinet. No statement was ever read into the record, however. First, Miguel Alfonso Martinez (Cuba) made a procedural objection, ${ }^{17}$ then Danilo Türk (Yugoslavia) stated that he had not seen or accepted any statement and therefore the chairman should not proceed until everyone had seen the text. Because it was 9:00 p.m. Friday, there was no time to resolve the matter. The following Monday the members informally agreed that there would not be any consensus statement read into the record on either the Baltics specifically or the current Soviet situation

14. Statement by the chairman, supra note 12 , at 199.

15. The Commission chairman, Enrique Bernales Ballesteros (Peru), visited the Sub-Commission in August on a matter unrelated to the Baltics situation. During his visit, he was asked in private about the promised Soviet investigation into the human rights violations in Latvia and Lithuania, and Ballesteros stated that he had not yet received any report from the Soviet Union regarding results from any investigation into the matter.

16. Summary Record of the 22nd Meeting, at 4, U.N. Doc. E/CN.4/Sub.2/1991/SR.22 (1991).

17. Martinez pointed out that the members were in the process of voting on agenda item 6 , which deals with human rights violations in specific countries, whereas Treat indicated that the consensus statement on the Soviet Union should be inserted in the record under agenda item 10 (b) on human rights and states of emergency. 
in general. Instead, each member had the opportunity to make individual comments for the record. Only a few members chose to speak. Treat expressed disappointment that the Sub-Commission had failed to take formal action on the Baltics before or after the unsuccessful coup.

\section{B. Cambodia}

The resolution on Cambodia focused on the "duty of the international community to prevent the recurrence of genocide." ${ }^{\prime 18}$ Adopted by a vote of fourteen in favor, four against, and four abstaining, with one member not participating, the resolution commended the efforts of all parties, and specifically Prince Sihanouk and Prime Minister Hun Sen, to come to a rapprochement. The Sub-Commission invited "all parties participating in the search for a peaceful settlement and the establishment of a democratic regime, and in particular the five permanent members of the Security Council, to take all necessary preventive measures to avoid conditions that could create for the Cambodian people the risk of new crimes against humanity." ${ }^{19}$ The Sub-Commission also requested that human rights be taught to the entire population of Cambodia and called on the UN Secretary-General to send a special delegation to all provinces in Cambodia and to the refugee camps in Thailand to examine the human rights situation.

\section{East Timor}

The Sub-Commission discussed but did not formally consider a resolution on East Timor; instead, the chairman read a very brief statement that had been negotiated between the Indonesian government and advocates for human rights in East Timor. ${ }^{20}$ The statement conveyed optimism about the upcoming visits to East Timor by the Special Rapporteur on Torture and by a group of Portuguese Parliamentarians. The chairman noted that the decision not to submit the draft resolution on East Timor was a gesture to promote a spirit of openness and to facilitate the work of the Special Rapporteur on Torture. Some members and NGOs, however, believed that in order to signal real progress Indonesia should allow a visit by an independent and credible

18. Sub-Comm'n Res. 1991/8, 1991 Report, supra note 1, at 34.

19. Id.

20. Summary Record of the 26 th Meeting, at 17, U.N. Doc. E/CN.4/Sub.2/1991/SR.26 (1991). 
NGO such as Amnesty International or the International Commission of Jurists. ${ }^{21}$

Indonesia's cooperation in 1991 contrasts with its lobbying in past years to avoid being the subject of a Sub-Commission resolution. In 1989 and 1990 the Sub-Commission adopted resolutions which noted the allegations of serious human rights violations in East Timor and called on Indonesia to allow international humanitarian groups to visit. ${ }^{22}$ In 1988, before the SubCommission began using the secret ballot, Indonesia's lobbying tactics succeeded in preventing the adoption of a resolution on East Timor. ${ }^{23}$

\section{El Salvador}

The Sub-Commission resolution on El Salvador, adopted 18-1-3, with one member not participating, reflected an attitude of hope, tempered by past experience, in commending the ongoing negotiations between the government and the opposition Frente Farabundo Martí para la Liberacíon Nacional (FMLN). ${ }^{24}$ An amendment by Theo van Boven (Netherlands) was incorporated into the resolution, noting the lack of substantial progress in the judicial inquiry into the 1989 murders of the rector and other staff members at Central American University. ${ }^{25}$ The Sub-Commission expressed satisfaction at the

21. More recent events will test Indonesia's stated commitment to achieving a peaceful resolution of the situation in East Timor. The delegation of Portuguese Parliamentarians had been scheduled to visit on 4 November, but the visit was canceled. On 12 November 1991, Indonesian soldiers opened fire on 1,000 mourners in a funeral procession in East Timor. Estimates of the number of people killed ranged from twenty to over 100 people. Two US journalists who witnessed the attack - and who assert that the killings were unprovoked and premeditated-were beaten. The Indonesian military issued a statement blaming separatist movements for the shootings and said officials of the local Roman Catholic church had been involved. See Indonesia Forces Open Fire on Mourners in East Timor, N.Y. Times, Nov. 13, 1991, at A8, col. 5. In a public statement the day after the killings, the commander of the army expressed regret for the incident and promised to conduct a full investigation. Jakarta Promises an Investigation of Army Shooting in East Timor, N.Y. Times, Nov. 14, 1991, at A6, col. 5. The UN Special Rapporteur on Torture was in East Timor at the time of the killings on 12 November but made no attempt to investigate the incident.

22. Sub-Comm'n Res. 1989/7, at 25, U.N. Doc. E/CN.4/Sub.2/1989/59 (1989); Sub-Comm'n Res. 1990/15, at 38, U.N. Doc. E/CN.4/Sub.2/1990/59 (1990).

23. Representatives of Indonesia reportedly contacted government officials around the world, who in turn exerted pressure on the experts from their respective countries to defeat the resolution. The Sub-Commission voted 10-9-5 to take no action on the 1988 draft resolution. See Brennan, Brody, \& Weissbrodt, supra note 1 , at 302.

24. Sub-Comm'n Res. 1991/11, 1991 Report, supra note 1, at 38.

25. In September 1991 a Salvadoran Army colonel and a lieutenant were found guilty of murder. Two other lieutenants and five soldiers were found innocent, even though four of the soldiers admitted firing the shots that killed the Jesuit priests, their cook, and her daughter. The trial did not answer the question whether anyone higher in the military command ordered the killings. The verdict marks the first time that a military officer has been convicted of killing a civilian in El Salvador. Five enlisted men in the National 
establishment of the UN Observer Mission in El Salvador (ONUSAL) entrusted with "the initial task, unprecedented in the history of the United Nations, of verifying implementation of the agreement on human rights as part of an integrated peace-keeping operation.." ${ }^{26}$

\section{E. Guatemala}

In its resolution on Guatemala, adopted 19-1-1, with two members not participating, the Sub-Commission expressed cautious optimism that the process of national reconciliation now underway will halt the persistent human rights violations by groups linked to the security forces. ${ }^{27}$ The SubCommission welcomed the progress in negotiations between the new government and the armed opposition. ${ }^{28}$ The resolution specifically pointed out the need to increase judicial independence, punish human rights violators, strengthen democracy, and initiate a fruitful dialogue with refugees and displaced persons-most of whom are indigenous peoples.

\section{F. Iran}

The Sub-Commission used very strong language in its resolution condemning the "deteriorating human rights situation" in Iran. ${ }^{29}$ Adopted by a vote of 19-2-1, with one member not participating, the resolution reflects the SubCommission's frustration at the continuation of severe human rights violations in Iran. The 1991 resolution contains a much more detailed description of flagrant abuses in Iran and gained greater support than the 1990 resolution, which was adopted $14-5-5 .{ }^{30}$ The Sub-Commission deplored the dramatic increase in executions in 1991, the recent arbitrary arrests of thousands of people, and the political assassinations abroad. The resolution expressed particular concern for the Baha'i community.

The Sub-Commission was disturbed at Iran's disregard of its commitment

Guard were convicted of killing three American nuns and a church worker in December 1980. Colonel Guilty in Jesuit Deaths in El Salvador, N.Y. Times, Sept. 30, 1991, at A1, col. 5. For a critical report on the trial, see International Commission of Jurists, El juicio por el asesinato de los lesuitas (Nov. 1991).

26. Sub-Comm'n Res. 1991/11, 1991 Report, supra note 1, at 38.

27. Sub-Comm'n Res. 1991/5, 1991 Report, supra note 1, at 27.

28. In April 1991 the government of Guatemala and the Guatemalan National Revolutionary Unity (URNG) signed the Mexico Agreement establishing a procedure and agenda for negotiations for a political solution to the internal armed conflict. The agenda includes respect for human rights and the rights of the indigenous populations. $I d$.

29. Sub-Comm'n Res. 1991/9, 1991 Report, supra note 1, at 35.

30. Sub-Comm'n Res. 1990/9, at 27, U.N. DoC. E/CN.4/Sub.2/1990/59 (1990) Ihereinafter 1990 Report]. 
to allow the International Committee of the Red Cross to visit and its refusal to allow the special representative of the Commission on Human Rights (Commission), Galindo Pohl, to visit prisons in Iran. The Sub-Commission noted Iran's implicit threat to institute a lawsuit against Special Representative Pohl if he makes future statements alleging Iranian government involvement in the assassination of an Iranian exile last year in Switzerland: "Iran stated that [Pohl] had referred to the assassination of Professor Kazem Rajavi in a manner that tended to allege involvement of the Government and that criminal charges had been pressed in Switzerland against a journalist who had made the same allegation." ${ }^{31}$ The resolution also noted that the Geneva Police Tribunal had recently issued a verdict in favor of that journalist. The Sub-Commission said that it was "disturbed at statements made by Iranian judicial officials and at laws advocating the torturing of prisoners and ordinary citizens, and especially at the widespread public flogging of women." ${ }^{\prime 2}$ It called on the Commission to extend the mandate of its special representative and called on Iran to allow him and the Red Cross access to Iranian prisons.

The Sub-Commission did not, however, specifically address three matters related to Iran's human rights record: the assassination of exiled former Iranian Prime Minister Shahpur Bakhtiar in Paris, the murder of the Japanese translator of Salman Rushdie's novel The Satanic Verses, and the attempted murder of the Italian translator of the same work. ${ }^{33}$ In 1990 the Sub-Commission passed a separate resolution condemning the assassination of Professor Kazem Rajavi, a former Iranian diplomat living in exile in Switzerland. ${ }^{34}$ Although the 1990 resolution did not directly accuse Iran of involvement in the assassination, it called upon the Commission's special representative on human rights in Iran to include information on the subject in his next report. The 1991 resolution on Iran did not specifically mention the Bakhtiar assassination but noted the "continuing wave of ... political assassinations abroad." 35 The Sub-Commission has not passed a resolution specifically addressing Iran's death sentence against Salman Rushdie or any of the repercussions arising from it, although the 1990 resolution concerning Rajavi's assassination did contain a general statement condemning "every assassination or threat of assassination of political dissidents or other persons wherever they live." 36

31. Sub-Comm'n Res. 1991/9, 1991 Report, supra note 1, at 35.

32. $l d$.

33. Hitoshi Igarashi was found stabbed to death in his office at Tsukuba University in Tokyo, Japan, on 12 July 1991. Nine days earlier Ettore Capriolo had been attacked and wounded by an Iranian in Milan, Italy. Both men had translated the novel, The Satanic Verses, by Salman Rushdie. In 1989 Iranian leader Ayatollah Ruhollah Khomeini issued a death sentence against Rushdie, claiming that his novel blasphemed the islamic faith. Rushdie has been in hiding since February 1989. Japanese 'Satanic Verses' Translator Slain, St. Paul Pioneer Press, July 13, 1991, at 4A, col. 2.

34. Sub-Comm'n Res. 1990/8, at 26, U.N. Doc. E/CN.4/Sub.2/1990/59 (1990).

35. Sub-Comm'n Res. 1991/9, 1991 Report, supra note 1, at 35.

36. Sub-Comm'n Res. 1990/8, 1990 Report, supra note 30, at 26. 


\section{G. Iraq and Kuwait}

In 1991, one year after Iraq's invasion of Kuwait and several months after the conclusion of the Persian Gulf War, the Sub-Commission again considered the human rights situation in Iraq and Kuwait. The Sub-Commission adopted a resolution on human rights violations in Iraq by a vote of 16-24 , with two members not participating in the vote. The resolution noted the "flagrant and massive violations of human rights committed by the Government of Iraq" and expressed deep concern for the "lives and safety of hundreds of thousands of Kurdish and Shi'ite Muslims fleeing an unprecedented wave of Government persecution which began in March 1991."137 The Sub-Commission also called upon Iraq to permit unhindered access by international organizations to those people in need of assistance and to cooperate with the Commission's Special Rapporteur on the human rights situation in Iraq. The resolution follows concerns expressed in the SubCommission's resolution of 1990, the first year in which the Sub-Commission succeeded in passing a resolution on human rights violations in Iraq. ${ }^{38}$

The Sub-Commission adopted a separate decision, under agenda item $4,{ }^{39}$ addressed to the needs of the civilian population in Iraq. ${ }^{40}$ The SubCommission appealed to all nations carrying out UN sanctions against Iraq to take urgent measures to prevent the deaths of thousands of innocent persons and to ensure that their needs for food and health care were met. The decision was adopted without a vote. After the decision was adopted, William Treat (United States) stated for the record that he would have voted against the draft decision if it had come to a vote.

The Sub-Commission's resolution on Kuwait reflected deep concern about the human rights situation following the withdrawal of Iraqi troops from Kuwait earlier this year. ${ }^{41}$ The resolution asked the Commission's Special Rapporteur on Kuwait to investigate allegations of arbitrary arrests, torture, unfair trials, enforced or involuntary disappearances, deaths in custody, possible extrajudicial executions, deportations, and other abuses against nonKuwaitis. Some Sub-Commission members were reluctant to adopt a resolution that appeared to criticize Kuwait, citing the extraordinary and understandably volatile situation in Kuwait immediately following the withdrawal of Iraqi troops. Awn Shawkat Al-Khasawneh (Jordan) pointed out,

37. Sub-Comm'n Res. 1991/13, 1991 Report, supra note 1, at 41.

38. See Brody, Convery, \& Weissbrodt, supra note 1, at 267-69.

39. Agenda item 4 is entitled "Review of further developments in fields with which the SubCommission has been concerned" and deals with subjects as varied as human rights and the environment, compensation for victims of gross violations of human rights, the right to freedom of expression, traditional practices affecting the health of women and children, and discrimination against HIV-infected people or people with AIDS.

40. Sub-Comm'n Dec. 1991/108, 1991 Report, supra note 1, at 85.

41. Sub-Comm'n Res. 1991/7, 1991 Report, supra note 1, at 33. 
however, that the resolution did not criticize Kuwait and that Kuwait itself had called for investigation of such charges. ${ }^{42}$ Theo van Boven (Netherlands) emphasized that the United Nations had been involved in the Iraq/Kuwait situation from the very outset, and that the Commission had established a special procedure - the Special Rapporteur on Kuwait-to examine the situation in Kuwait. The resolution was adopted 16-4-2, with one member not participating. The government of Kuwait exercised its right to speak after the vote. It stated that many of the allegations of human rights abuses were aimed at sowing dissension and hiding the fact of collaboration during Iraq's occupation of Kuwait; now all of the collaborators claimed to be victims of ill-treatment. The government did acknowledge that individual acts of vengeance had occurred and stated that it was moving quickly to redress the harm done.

\section{H. Israeli-Occupied Territories}

The Sub-Commission adopted two resolutions concerning the Palestinian and other Arab territories occupied by Israel. One resolution echoed the numerous concerns expressed in past resolutions: it condemned Israel's continued occupation, persistent human rights abuses, construction of settlements, and disregard of UN resolutions as well as international law principles. It also reiterated support for an international peace conference on the Middle East. ${ }^{43}$ The resolution was adopted 16-2-4, with one member not participating.

A second resolution recommended that the Economic and Social Council (ECOSOC) ask the International Court of Justice (ICJ) to render an advisory opinion on "the legal consequences for States arising from the building by Israel of settlements in the territories occupied since 1967, notwithstanding Security Council resolutions 446 (1979) and $465(1980) .{ }^{\prime 44}$ The resolution attracted less support than the first resolution: 10-4-6, with one member not participating. Some members opposed the request for an ICJ opinion because they believed that existing UN Security Council resolutions already left no

42. In a note verbale to the United Nations, the Kuwaiti government did not call for an outside investigation but stated that it was diligently prosecuting all persons accused of engaging in acts of vengeance in the early days following the liberation of Kuwait. It also noted that it had invited the Red Cross to visit and hold private interviews with any detainees in Kuwait. Note verbale dated 14 August 1991 from the Permanent Mission of Kuwait to the United Nations Office at Ceneva addressed to the Chairman of the SubCommission on Prevention of Discrimination and Protection of Minorities, U.N. Doc. E/ CN.4/Sub.2/1991/58 (1991).

43. Sub-Comm'n Res. 1991/6, 1991 Report, supra note 1 , at 30.

44. Sub-Comm'n Res. 1991/38, 1991 Report, supra note 1, at 81. Cf. Advisory Opinion on the Legal Consequences for States of the Continued Presence of South Africa in Namibia, 1971 I.C.J. 16. 
doubt that the settlements were illegal. Khalil (alternate, Egypt) withdrew as a sponsor of the original resolution, citing that very reason, though it was speculated that pressure from his foreign ministry forced the change. The government of Syria also stated that the resolution would weaken the Security Council resolutions and, in any case, was a political matter. Stanislav Chernichenko (Soviet Union), despite his support of the resolution, also expressed concern that the Sub-Commission was exceeding its mandate because of the political, rather than human rights, focus of the resolution. Awn Shawkat al-Khasawneh (Jordan) countered that the resolution in no way called into question the illegality of the Israeli settlements and stated that the resolution addresses consequences for third party states. William Treat (United States), after noting that his government has always opposed the settlements, stated that the timing of the resolution was unwise in view of the imminent Middle East peace conference. ${ }^{45}$

\section{Somalia}

The resolution on Somalia was considered under the agenda item on the realization of economic, social, and cultural rights and marked the first time that the Sub-Commission has adopted a resolution on a Sub-Saharan African country. The government of Somalia, which spoke just before the vote, welcomed the resolution and asked the Sub-Commission to adopt it by consensus, which the members did. The resolution urged the international community to take immediate steps to prevent starvation and total economic devastation in the wake of the collapse of the previous government following "20 years of gross violations of human rights and the ensuing civil war." ${ }^{16}$ The resolution specifically noted that "internal displacement has removed people in Somalia not only from their homes and lands, but from meaningful participation in their Government, and from their right to development."

\section{J. South Africa}

The resolution on South Africa contains words of encouragement but calls for continued vigilance over the process to end apartheid. ${ }^{47}$ Adopted

45. The Middle East peace conference began in Madrid, Spain, on 30 October 1991, and included direct talks between Israel and Syria, Lebanon, and a joint Jordanian-Palestinian delegation. A second round of talks took place in Washington, DC, in early December. Mideast Talks Due to Resume; Rough Road Expected, L.A. Times, December 9, 1991, at A6, col. 1.

46. Sub-Comm'n Res. 1991/29, 1991 Report, supra note 1, at 64.

47. Sub-Comm'n Res. 1991/4, 1991 Report, supra note 1, at 25. 
20-0-1, with two members not participating, the resolution welcomes the repeal of key apartheid legislation but notes that many political prisoners, exiles, and other "painful legacies" of apartheid remain. The Sub-Commission condemned the recently acknowledged secret government funding of the Inkatha party to spread violence in the black community. The SubCommission also urged the international community to maintain sanctions and other forms of pressure against South Africa until the creation of conditions which will lead to negotiations for a constitutional transfer of power to a democratic, non-racial government.

\section{K. Tibet}

The most notable resolution, as well as the closest vote $(9-7-4$, with two members not participating), involved the human rights situation in Tibet. ${ }^{48}$ The resolution marks the second time that Sub-Commission members have addressed human rights concerns in China. The Sub-Commission passed a resolution in 1989 regarding China's suppression of pro-democracy demonstrators in Tiananmen Square. ${ }^{49}$ The 1991 resolution on Tibet has greater significance, however, because it is aimed at longstanding Chinese policy in Tibet rather than at a single past event. Moreover, the language of the 1991 resolution on Tibet is stronger than the wording of the previous resolution on China. In 1989 the Sub-Commission merely expressed its "concern[] about the events [in Tiananmen Square] which took place recently in China and about their consequences in the field of human rights" and "appeal[ed] for clemency" for persons deprived of their liberty. ${ }^{50}$ The 1991 resolution on Tibet expresses concern at the "continuing reports of violations of fundamental human rights and freedoms which threaten the distinct cultural, religious and national identity of the Tibetan people" and called upon the Chinese government "fully to respect the fundamental rights and freedoms of the Tibetan people." 51

China lobbied hard to prevent passage of the resolution and to present its side of the story, even including a lengthy film on Tibet at a social reception at its mission in Geneva. Before the vote the Sub-Commission member from China, Tian Jin, stated that the resolution reflected persistent distortions about Tibet and its history. He charged that the resolution represented political manipulation under the guise of human rights, and that a handful of persons

48. Sub-Comm'n Res. 1991/10, 1991 Report, supra note 1, at 37.

49. Sub-Comm'n Res. 1989/5, at 23, U.N. Doc. E/CN.4/Sub.2/1989/58 (1989). This action marked the first time the Sub-Commission had passed a resolution directed at one of the

50. $l d$. permanent members of the Security Council.

51. Sub-Comm'n Res. 1991/10, 1991 Report, supra note 1, at 37. 
and their foreign sponsors want to see China in constant turmoil. Tian Jin claimed that such persons cherish the dreams of the old colonialists, which will never be realized. Immediately after the vote, the government of China angrily denounced the resolution, calling it "null and void" and stating that it had no effect on China. China's reaction and even its words were identical to its reply following passage of the 1989 resolution. ${ }^{52}$

\section{Confidential 1503 Procedure}

The Sub-Commission employs a confidential procedure, authorized by ECOSOC resolution $1503,{ }^{53}$ to examine communications alleging consistent patterns of gross violations of human rights in specific countries. The SubCommission's Working Group on Communications meets in private for two weeks prior to the Sub-Commission session to consider such communications. The working group forwards specific country situations to the SubCommission, which then decides, in private session, which situations to refer to the Commission's attention.

In 1991 the Sub-Commission reportedly decided to transmit to the Commission communications on the following seven countries: Bahrain, Chad, Myanmar (Burma), Somalia, Sudan, Syria, and Zaire. ${ }^{54}$ The Sub-Commission also decided to review pending communications concerning Bhutan and Turkey at its 1992 session for possible referral to the Commission's attention. In addition, the Sub-Commission reportedly terminated its confidential examination of the human rights situation in Guatemala.

The Sub-Commission adopted another decision, which it made public, on communications regarding gross violations of human rights of POWs and civilians detained in military prisons and camps during the Second World War. ${ }^{55}$ By a vote of 15-3-1, the Sub-Commission decided that the 1503 procedure could not be applied as a reparation or relief mechanism to compensate surviving victims or next of kin of persons who died as a result of ill-treatment, torture, or forced labor during detention.

\section{STUDIES AND REPORTS}

The Sub-Commission received final reports on two studies and recommended that its parent bodies - the Commission and ECOSOC-approve one new

52. See Maher \& Weissbrodt, supra note 1, at 295-96, n.25.

53. ECOSOC Res. 1503 (XLVIII), U.N. ESCOR, 48th Sess., Supp. No.1A, at 8, U.N. Doc. E/ 4832/Add.1 (1970).

54. See Zoller, supra note 1, at 13; Brody, supra note 1.

55. Sub-Comm'n Dec. 1991/104, 1991 Report, supra note 1, at 84. 
study. Final reports were submitted by Leandro Despouy (Argentina) on human rights and disability, ${ }^{56}$ and by Halima Embarek Warzazi (Morocco) on traditional practices affecting the health of women and children. ${ }^{57}$ The Sub-Commission nonetheless requested that Warzazi's mandate be extended for two years to enable her to present to the Sub-Commission in 1993 a plan of action and a report on a regional seminar to take place in Asia. The Sub-Commission requested that Erica-Irene Daes (Greece) be entrusted with a new study on the ownership and control of the cultural property of indigenous peoples, which will build upon the working paper she presented at the 1991 session.

Although many studies were on the agenda, the Sub-Commission was not able to discuss all of them in depth during the 1991 session. Studies on the following topics, however, were extensively discussed: investments in South Africa; protection of minorities; freedom of expression; administration of justice, including the right to a fair trial and the independence of the judiciary and of lawyers; and economic, social, and cultural rights. The SubCommission also discussed the preliminary report on human rights and the environment, and encouraged the special rapporteur to continue to explore the issue in greater depth. Other studies to which the Sub-Commission devoted less time in 1991 included the following subjects: the right to restitution, compensation, and rehabilitation for victims of gross violations of human rights and fundamental freedoms; human rights and youth, including a draft charter on the rights and freedoms of youth; and discrimination against HIV-infected people or people with AIDS.

\section{A. Completed Studies}

The Sub-Commission received final reports from Leandro Despouy (Argentina) on human rights and disability and from Halima Embarek Warzazi (Morocco) on traditional practices affecting the health of women and children. Despouy's study, which will be published in braille and on cassette, presents a survey of the numerous causes of disability and the types of discrimination encountered by disabled persons. ${ }^{58} \mathrm{He}$ recommends that national legislation be upgraded to meet international standards for the treatment of the disabled. He also notes that the disabled are at a legal disadvantage compared to other vulnerable groups, such as refugees, women, and migrant workers, because the latter are each protected by a single body of binding norms. During the discussion of this issue, several

56. U.N. Doc. E/CN.4/Sub.2/1991/31 (1991).

57. U.N. Doc. E/CN.4/Sub.2/1991/6 (1991).

58. U.N. Doc. E/CN.4/Sub.2/1991/31 (1991). 
deaf persons made statements using sign language, reinforcing Despouy's point that the disabled themselves are the experts in this field. The importance of including the disabled was further highlighted at a concert that took place in central Geneva at which a sign language interpreter signed the lyrics for the deaf members of the audience. The Sub-Commission praised the efforts of Despouy and the many NGOs who contributed information. The SubCommission urged the implementation of Despouy's recommendations, including closer coordination among specialized agencies and UN bodies dealing with the human rights of disabled persons. ${ }^{59}$

In presenting her final report on traditional practices affecting the health of women and children, Warzazi stressed both the progress achieved and the great amount of work yet to be done. ${ }^{60}$ For example, when she began the study in 1983 the issue of "female circumcision" was taboo; today, there is much greater awareness of the harmful effects of the practice, and it is frankly recognized as female genital mutilation. Nevertheless, the practice remains widespread in Africa and in parts of Asia. The report examines the physical consequences of female circumcision and the cultural context in which it persists. The report also explores other traditional practices that adversely affect the health of women and children, such as son preference, nutritional taboos related to pregnancy, and early marriage and childbearing. The Sub-Commission requested that Warzazi's mandate be extended for two years to enable her to present to the Sub-Commission in 1993 a plan of action for the elimination of such harmful practices and to present a report on a regional seminar to take place in Asia. The Sub-Commission also asked the UN Centre for Human Rights to provide a full-time staff member to pursue this issue. ${ }^{61}$

\section{B. Apartheid in South Africa and Racism Throughout the World}

The Sub-Commission agenda item on South Africa ${ }^{62}$ provided the setting for prolonged discussion of the changing situation in that country. ${ }^{63}$ Although

59. Sub-Comm'n Res. 1991/19, 1991 Report, supra note 1, at 50.

60. U.N. Doc. E/CN.4/Sub.2/1991/6 (1991).

61. Sub-Comm'n Res. 1991/23, 1991 Report, supra note 1, at 55.

62. Under agenda item $5(\mathrm{~b})$, the Sub-Commission examines "adverse consequences for the enjoyment of human rights of political, military, economic and other forms of assistance given to the racist and colonialist regime of South Africa."

63. Prior to the August 1991 session of the Sub-Commission, the South African government repealed the last remaining legal pillars of apartheid: the Land Acts, the Group Areas Act, and the Population Registration Act. It also released some political prisoners and allowed political exiles to return to South Africa. Many observers nonetheless stated that the government's formal actions did not represent irreversible progress toward dismantling apartheid because other measures still in force or about to be enacted would function to maintain a de facto apartheid system. This position was buttressed by President F.W. DeKlerk's admission in July 1991 that the government had covertly funded the Inkatha Freedom Party, which has been accused of instigating large-scale violence against rival African National Congress supporters. 
the 1991 annual report by Ahmed Khalifa (Egypt) ${ }^{64}$ differed little from last year's report, Khalifa's introductory comments set the stage for a discussion about the role of the international community in eliminating the apartheid system in South Africa. Most of the discussion centered on whether it was too early to lift economic sanctions against South Africa. Khalifa spoke eloquently of the danger of indifference and the fear of losing the world spotlight now that apartheid had begun to crumble. He presented an extremely pessimistic view of the changes in South Africa and criticized Denmark, the European Economic Community, and in particular the United States for lifting sanctions against South Africa. ${ }^{65}$ Khalifa asserted that the US action was "astonishly premature" and a "glimpse of post--Gulf War politics" 66 that was especially disappointing because the United States had been in the vanguard in imposing sanctions against South Africa. Remarks by William Treat (United States) reflected much greater optimism about the changes underway in South Africa. He noted that Khalifa's own report mentions the great extent of US disinvestment in South Africa. ${ }^{67}$ Other SubCommission members filled out the spectrum of views about whether change in South Africa was, in fact, irreversible and at what point sanctions should be lifted..$^{68}$ The Sub-Commission asked Khalifa to continue to update his

64. U.N. Doc. E/CN.4/Sub.2/1991/13 and Add.1 (1991) [hereinafter South Africa Report]. Since 1978 Khalifa has presented to the Sub-Commission a report that includes the names of banks, transnational corporations, and other organizations whose activities constitute assistance to apartheid in South Africa.

65. In July 1991 President Bush terminated enforcement of sanctions imposed under section 311 of the 1986 US Comprehensive Anti-Apartheid Act (CAAA). He based his decision on a finding that South Africa had complied with the five conditions set forth in the CAAA: (1) the release of all political prisoners; (2) the repeal of the state of emergency; (3) the unbanning of democratic political parties; (4) the repeal of the Group Areas Act and the Population Registration Act; and (5) an agreement to enter into good faith negotiations with truly representative members of the black majority without preconditions. President Bush explained his decision by noting that Congress intended the CAAA to serve as an incentive for South Africa to move toward good faith negotiations, not as a reward to be withheld until the apartheid system was completely eliminated. Despite President Bush's action under the CAAA, sanctions contained in other legislation remained. For example, the announcement did not affect the ban on US support for International Monetary Fund loans to South Africa, exports to the South African military and police, Export-Import Bank loans to South Africa, and export of arms and materiel to South Africa.

66. Summary Record of the 5th Meeting, at 3-4, U.N. Doc. E/CN.4/Sub.2/1991/SR.5 (1991).

67. The report notes that, among major countries, the United States has disinvested almost 62 per cent, the United Kingdom 31 per cent, and Germany about 22 per cent. South Africa Report, supra note 64, at 5.

68. Theo van Boven (Netherlands) drew the Sub-Commission's attention to the fact that the Swiss Bank Corporation located in the Palais des Nations in Geneva, where the SubCommission holds its meetings, has substantial dealings with South Africa in contravention of UN policies. A UN official later explained that UN headquarters had approved the use of this bank, at the minimal necessary level to provide banking services at the Palais, out of necessity. In 1988 the previous bank had announced its intention to cease its operations at the United Nations; negotiations with other banks not linked to South Africa 
annual report and called upon all governments and organizations to maintain sanctions until apartheid is completely dismantled. It also requested the Secretary-General to approach the South African government about a possible visit by Khalifa for the purpose of updating his report. ${ }^{69}$

Sub-Commission members also deplored the apparent resurgence of other manifestations of racial discrimination around the world. Several members noted increased xenophobia and extreme nationalism in Central and Eastern Europe, a rise in anti-Semitism and fascist sentiments, and an upsurge in violence against migrant workers and refugees in Western Europe. The Sub-Commission adopted by consensus a lengthy resolution on measures to combat racism and racial discrimination. ${ }^{70}$ It noted that the principal objectives in combating racism have not been attained and recommended that the General Assembly launch a third decade to combat racism and racial discrimination, to begin in 1993. It recognized that conflicts over economic resources intensify racial conflict and that racism can best be defeated by a combination of economic, legislative, and educational measures. The resolution also requested that a special rapporteur of the SubCommission be appointed to update the study on racial discrimination prepared in 1976 by Hernan Santa Cruz, in the light of recent trends of racism, racial discrimination, and xenophobia.

\section{Minorities}

Sub-Commission members extensively discussed the preliminary report by Asbjorn Eide (Norway) on the protection of minorities." Although some members expressed concern that the study did not yet define the term "minority" and debated whether religious as well as ethnic minorities should be included, ${ }^{72}$ everyone agreed that the study was extremely valuable and

failed, and the United Nations faced the prospect of having no banking facilities on the premises as of 1 July 1990. The United Nations is still seeking a bank with no ties to South Africa to provide banking services at the Palais in Geneva.

69. Sub-Comm'n Res. 1991/1, 1991 Report, supra note 1, at 21.

70. Sub-Comm'n Res. 1991/2, 1991 Report, supra note 1, at 21.

71. U.N. Doc. E/CN.4/Sub.2/1991/43 (1991) [hereinafter Protection of Minorities].

72. Eide initially excluded the category of religious minorities from the study because they were the subject of a special declaration - the Declaration on the Elimination of All Forms of Intolerance and of Discrimination Based on Religion or Belief-as well as a special procedure, the Special Rapporteur on Religious Intolerance appointed by the Commission on Human Rights. Several NGOs that replied to Eide's questionnaire urged the inclusion of this category, noting that Article $\mathbf{2 7}$ of the International Covenant on Civil and Political Rights includes religious minorities as well as cultural and liguistic groups and that the draft declaration on the rights of minorities also includes religious groups. Upon reflection, Eide recognized the difficulty of separating ethnic from religious identification and decided to broaden the study to include religious minorities. See id. at 3-4. 
timely in light of current problems involving minorities in Ethiopia, the Soviet Union, Yugoslavia, and elsewhere.

This enthusiastic endorsement by Sub-Commission members contrasts with the negative reaction of the Sub-Commission's parent bodies toward its past work on the minorities issue. Although the name of the Sub-Commission makes clear that the protection of minorities is central to its mandate, the Sub-Commission's early efforts to study the issue provoked such controversy that its very existence as a UN body was threatened. ${ }^{73}$ Today, however, with the apparent end of the Cold War, the issue of minorities has come to the forefront of world attention, as best illustrated by the violent disintegration of Yugoslavia into separate republics and the repeated failed attempts to mediate a cease-fire between the ethnic factions.

Mindful of the extreme political sensitivity of the subject, ${ }^{74}$ Eide has focused his study on the search for peaceful and constructive solutions to problems involving minorities rather than on the specific rights of members of minority groups. ${ }^{75}$ The study will be largely based on national experiences in dealing with minorities. Eide is seeking information from two sources: first, from questionnaires sent to governments, specialized agencies, and nongovernmental organizations; and second, from states' reports to UN treaty-monitoring bodies - in particular, reports submitted under the International Covenant on Civil and Political Rights (ICCPR), especially Article

73. See Brennan, Brody, \& Weissbrodt, supra note 1, at 322-23; Maher \& Weissbrodt, supra note 1, at 312; Humphrey, The United Nations Sub-Commission on the Prevention of Discrimination and the Protection of Minorities, 62 AllL 869 (1968).

74. The speeches by the observers from Hungary and Turkey illustrate the differing government views and sensitivities on the issue of minorities. Hungary welcomed the renewed focus on minorities and acknowledged that its own record on the issue was far from perfect. It affirmed that minority rights were not the exclusive internal affair of states and noted Hungary's vested interest in seeing solutions to minority problems implemented in countries where Hungarian national minorities lived. Summary Record of the 20th Meeting, at 7-8, U.N. Doc. E/CN.4/Sub.2/1991/SR.20 (1991). In contrast, Turkey assailed Western countries' hypocritical focus on minority problems in non-Western countries, especially developing countries, while ignoring the problems of minority groups in their own countries, particularly problems with respect to migrant workers. Turkey accused human rights activists of harboring political rather than humanitarian motives and of promoting destabilization of developing countries by aligning themselves with minorities or extreme leftwing ideological groups. It expressed resentment that countries accused of minority rights violations were painted as evil by human rights groups that failed to understand the need for territorial integrity, peace, and stability. Id. at -9-10.

75. The Commission is in the process of drafting a Declaration on the Rights of Persons Belonging to National, Ethnic, Religious and Linguistic Minorities. Among the concerns expressed in the present draft are whether to define "minority," and if so, what the appropriate definition should be; whether the draft should simply prevent discrimination or go a step further to promote the separate identities of minorities through the preservation of separate cultures and languages; and whether minority rights should be thought of as only collective rights or also as individual rights. See Parker \& Weissbrodt, Major Developments at the UN Commission on Human Rights in 1991, 13 Hum. Rts. Q. 573, 612-13 (1991). 
27, and the International Convention on the Elimination of All Forms of Racial Discrimination. ${ }^{76}$

Eide also maintains that a precise definition of "minority" is not necessary in order to pursue the study on minorities. ${ }^{77}$ Indeed, the Sub-Commission's past history of efforts to formulate a definition has convinced Eide that he would not be able to carry out the study if he were to begin with a precise definition. ${ }^{78}$ Instead, Eide uses the term "minority" in a broad sense to include "nationalities, ethnic, linguistic or cultural groups which in significant respects are different from other groups in a sovereign State."79 Eide concedes that the definition allows governments responding to his questionnaire to decide arbitrarily whether minorities exist in their countries, but he maintains that such responses are nonetheless useful because they reveal the policies of recognition pursued by the different governments. ${ }^{80}$

Eide will analyze the national experiences with minorities in the light of six guidelines for devising peaceful and constructive solutions to problems involving minorities. His first guideline declares the paramount importance of nondiscrimination and full participation of all groups. Eide stresses the need for complete impartiality in the administration of justice and the actions of law enforcement and security personnel. Full democracy and the rule of law form the basis of any effort to solve minority problems. ${ }^{81}$ The second guideline asserts the need to promote minority rights in a manner consistent with the unity and stability of states. Eide states that the most important principle is self-determination, but notes that this principle is intimately linked to pluralist democracy and does not mean that every identifiable minority group has the right to secede from a state. ${ }^{82}$ The third guideline notes the danger posed by ethnic conflict to regional as well as national security. Eide illustrates how conflicts can spiral out of control when the parties fail to understand or communicate with each other. He further states that international recourse mechanisms could act as an important safety valve when minority groups believe that national institutions are biased. ${ }^{83}$

Eide cites the importance of "equality in fact" for minorities in the report's

76. Protection of Minorities, supra note 71, at 1-2.

77. Id. at 2.

78. Eide points out that the Sub-Commission has repeatedly tried since 1947 to adopt a definition of minorities. The most recent proposed definition, by Jules Deschênes in 1985 , failed to meet with Sub-Commission approval. Id. at 3.

79. Id. at 2 .

80. Id. at 3 .

81. Id. at 6 ; Eide notes that there are probably only three basic limitations to the nondiscrimination principle: (1) minorities cannot demand special privileges and thus obtain a better status than others in society; (2) they cannot use religious or cultural practices to impede others from exercising their religion or culture; and (3) their activities must not violate public order as the concept is understood in a fully democratic society. $I d$. at 7.

82. Id. at 8 .

83. Id. at 9-11. 
fourth guideline. When a minority has been discriminated against in the past, the principle of equality might dictate that members of minority groups receive different treatment-special measures or status - than that accorded members of the majority group. ${ }^{84}$ The fifth guideline highlights the role of the development process in inter-ethnic conflict. Eide points out that development often increases economic disparities among groups, and that groups attach different values to different kinds of development. Although Eide hesitates to give a group an effective veto over any development project, he states that governments should consult the people affected before proceeding. If a government cannot obtain their free and informed consent, it should provide the option of voluntary resettlement or effective compensation. Finally, the sixth guideline points out the need to respect the human rights of majorities when adopting measures to protect minorities. Any special measures taken to overcome past discrimination against minorities must cease after the objectives for which they were adopted have been achieved. In no case may members of either the majority or a minority group pursue their goals through means or methods that constitute violations of human rights. ${ }^{85}$

The Sub-Commission, in resolution 1991/22, endorsed Eide's guidelines and asked him to submit an updated report in 1992 in preparation for a final report in $1993 .{ }^{86}$ The resolution is substantively innovative because it turns the Sub-Commission into an operational body by authorizing Eide to visit three countries on different continents and to make contact with the minorities as well as the governments. It was understood informally that one of the countries to be visited by Eide would probably be the Soviet Union.

\section{Freedom of Expression}

The updated preliminary report ${ }^{87}$ on freedom of expression drew praise for its comprehensive treatment of the issues and sparked some criticism of its

84. Id. at 11-12. In this regard, Eide expresses his intention to draw upon the work of the Committee on the Elimination of Racial Discrimination, which has often addressed the issue of special measures or status for minority groups. $/ d$. at 12 .

85. Id. at 14.

86. 1991 Report, supra note 1 , at 53. In a separate resolution on the minorities issue, the Sub-Commission noted the particular vulnerability of persons belonging to the Roma community (gypsies) and appealed to all countries having Roma living within their borders to accord them all the rights enjoyed by the rest of the population. Sub-Comm'n Res. 1991/21, 1991 Report, supra note 1, at 52.

87. U.N. Doc. E/CN.4/Sub.2/1991/9 (1991) [hereinafter Freedom of Expression]. A preliminary report was presented at the 1990 session of the Sub-Commission, but the members did not have adequate time to discuss it. The Sub-Commission asked the rapporteurs to update the preliminary report and present it to the 1991 session. See Brody, Convery, \& Weissbrodt, supra note 1 , at 283. 
conclusion that the right to free expression must sometimes yield to the right to be free from racial discrimination. Critics charged that the report's notion of "permissible restrictions" would inevitably open the door to widespread abuse and restriction on expression. The report's authors, Louis Joinet (France) and Danilo Türk (Yugoslavia), pointed to the report's emphasis on the link between democracy and free expression and to the need to keep the category of "permissible restrictions" on free speech very narrow.

In their updated report, Joinet and Türk respond to comments received on last year's preliminary report and pay particular attention to two issues linked to current events: first, freedom of expression versus the struggle against racial discrimination; and second, freedom of expression and information in armed conflicts. The rapporteurs conclude that in the first instance restrictions on expression may be justified, whereas in the latter case restrictions entail serious risks. ${ }^{88}$ The report reiterates that the right to nondiscriminatory treatment is a fundamental right guaranteed by all international human rights instruments, ${ }^{89}$ and it cites several instruments which expressly or impliedly permit restrictions on free expression, especially in pursuit of the elimination of racism. ${ }^{90}$ The authors state that the concept of the "rights of others" seems to be the only justification for restrictions needed in the struggle against racism. Other justifications too easily serve as pretexts for

88. Freedom of Expression, supra note 87 , at 1 .

89. Id. at 11 . The report also notes that "it would be desirable that international instruments, before justifying measures that restrict freedom of expression, should perform their educational function properly by avoiding the use of such a term as 'race' which, when applied to human beings, has no scientific meaning." Id.

90. The report specifically mentions the following human rights instruments: (1) Universal Declaration of Human Rights, Article 29: Restrictions on the rights guaranteed therein are permissible "solely for the purpose of securing due recognition and respect for the rights and freedoms of others and of meeting the just requirements of morality, public order and the general welfare in a democratic society." (2) Conference on Security and Cooperation in Europe (CSCE), Document of the Copenhagen Meeting of the Conference on the Human Dimension of the CSCE of June 1990, para. 9.1: Exercise of the right to freedom of expression "may be subject only to such restrictions as are prescribed by law and are consistent with international standards." (3) American Convention on Human Rights, Article 29: "No provision of this Convention shall be interpreted as: (a) permitting any State Party, group, or person to suppress the enjoyment or exercise of the rights and freedoms recognized in this Convention or to restrict them to a greater extent than is provided for herein." (4) The same relevant language is found in Article 17 of the European Convention on Human Rights and Article 5 of the International Covenant on Civil and Political Rights. (5) Civil and Political Covenant, Article 20: "Any propaganda for war shall be prohibited by law," and "[a]ny advocacy of national, racial or religious hatred that constitutes incitement to discrimination, hostility or violence shall be prohibited by law." (The rapporteurs assert that this article refers by implication to the notion of indoctrination and false information or disinformation.) (6) International Convention on the Elimination of all Forms of Racial Discrimination, Article 4: "States Parties ... undertake to adopt immediate and positive measures designed to eradicate all incitement to, or acts of, Iracial hatred and discrimination" and undertake to "declare an offence punishable by law all dissemination of ideas based on racial superiority or hatred, incitement to racial discrimination." Freedom of Expression, supra note 87, at 9-11. 
censorship. For example, the notion of "morality" carries the risk of outlawing something which is merely not accepted by everybody, and the idea of "public order" is so vague as to invite abuse. ${ }^{91}$ Joinet and Türk also review decisions of the Human Rights Committee and the European Commission of Human Rights relevant to restrictions on free speech for the purpose of protecting the right to nondiscriminatory treatment. ${ }^{92}$

The second issue highlighted in the report is freedom of expression and information during armed conflicts. The need to ensure "state security" is the usual justification for restrictions on expression and information. Using last year's Persian Gulf War as an example, Joinet and Türk maintain that freedom of expression and information should only be restricted to the extent necessary to save lives and to avoid the risk of informing the enemy before or during a military operation. Once the operation is over, the free flow of information should be restored.${ }^{93}$ The rapporteurs point out that uncensored press reports serve several valuable functions, including providing information on whether belligerents are respecting the principles of the Geneva Conventions ${ }^{94}$; avoiding the "risk of disinformation in giving [credence], by omission, to the idea of a "clean war" "95; and mobilizing public opinion to condemn, in general, the use of force and, more specifically, to help prevent violations of international standards against torture, use of chemical weapons, and indiscriminate bombing. ${ }^{96}$

Although Joinet and Türk state that the purpose of their report is not to endorse the system of "permissible restrictions" on free speech but rather to describe it and analyze its risks, ${ }^{97}$ the report was criticized by a few observers at the Sub-Commission for devoting too much attention to permissible restrictions and not placing enough emphasis on ways to promote and expand the exercise of the right to free expression. The US observer, while endorsing some basic points contained in the report, objected to the implication that "freedom of expression and freedom of the press might be

91. ld. at $9-10$.

92. Id. at $12-15$.

93. Id. at 23.

94. The rapporteurs state that the obligations under the Geneva Conventions of 1949 include respect for various measures to protect the civilian population and in particular the prohibition of indiscriminate bombing. $/ d$. at 21 . The latter claim is not correct, however. The Geneva Conventions do not mention indiscriminate bombing. A later instrument, the 1977 Protocol I to the Geneva Conventions, does prohibit "indiscriminate attacks," including "attack[s] which may be expected to cause incidental loss of civilian life, injury to civilians ... . which would be excessive in relation to the concrete and direct military advantage anticipated." Article 51, Protocol Additional to the Geneva Conventions of 12 August 1949 Relating to the Protection of Victims of International Armed Conflicts (Protocol I), opened for signature 12 Dec. 1977, U.N. Doc. A/32/144, Annex I, reprinted in 16 I.L.M. 1391 (1977).

95. Freedom of Expression, supra note 87, at 24.

96. Id.

97. Id. at 4 . 
classified as subordinate rights that can be violated by the use of so-called 'permissible restrictions.' " He also criticized Joinet and Türk by stating that the action of "banning newspaper editors for 'recidivism' involving recurring violations of press restrictions" - a penalty which the rapporteurs found acceptable-was "precisely the legal technique used in South Africa to stifle press critics of Apartheid." 98 The NGO World Press Freedom Committee (WPFC) ${ }^{99}$ argued forcefully that the report's discussion of permissible restrictions has the effect of "legitimizing" restrictions on press freedom. ${ }^{100}$ The NGO representative rejected the report's distinction between the absolute right to freedom of opinion and the relative right to freedom of expression, inquiring what use is the right to hold an opinion if a person may not express it? The WPFC advocated the approach of the US First Amendment, which contains an unqualified right to free speech and leaves it to the courts to determine any necessary restrictions on a case-by-case basis.

In general, however, most Sub-Commission participants expressed support for the Joinet/Türk report on freedom of expression. The NGO Article $19^{101}$ strongly endorsed the report, particularly its conclusion that "a person imprisoned on the sole grounds that he has expressed his opinion is of necessity detained arbitrarily, unless that opinion was expressed in defiance of a permissible restriction" and that "even if the opinion expressed is open to sanction by virtue of a permissible restriction, that sanction should never go so far as imprisonment." 102 In this regard, Joinet and Türk asked that their report be communicated to the Commission's Working Group on Arbitrary Detention, established in 1991, because of the many individuals detained for peacefully expressing their opinions. ${ }^{103}$ The Sub-Commission members praised the comprehensive report and asked joinet and Türk to present their final report in $1992 .{ }^{104}$

98. Statement by J. Kenneth Blackwell, US Head of Delegation to the UN Human Rights Commission, on "The Right to Freedom of Opinion and Expression," 28 Aug. 1991.

99. The World Press Freedom Committee (WPFC) represents thirty-four journalistic organizations on five continents and spoke on behalf of its own members as well as the International Federation of Newspaper Publishers and the International Press Institute. Some observers expressed concern that the US government had reportedly insisted that the WPFC be added to the speakers list even though the list had already been closed. The United States stated that the WPFC had sent a fax to the US mission in Geneva within the time limit requesting that the United States place it on the speakers list.

100. Statement of the World Press Freedom Committee, 29 Aug. 1991.

101. Article 19 is an international NGO that promotes freedom of expression and defends victims of censorship throughout the world. Established in 1986, it takes its name from Article 19 of the Universal Declaration of Human Rights, which proclaims the right to freedom of opinion and expression and the right to seek, receive, and impart information and ideas through any media.

102. Statement by Article 19, 29 Aug. 1991, quoting Freedom of Expression, supra note 87, at 6 .

103. Freedom of Expression, supra note 87, at 5.

104. Sub-Comm'n Res. 1991/39, 1991 Report, supra note 1, at 82. 


\section{E. Human Rights and the Environment}

The Sub-Commission received a preliminary report on human rights and the environment by Fatma Zohra Ksentini (Algeria). ${ }^{105}$ Ksentini concludes that a "right to the environment" has emerged but is "still in gestation" and is "impossible to define except in terms of a series of objectives designed to protect the environment and to safeguard the fundamental rights of the human being and the interests of future generations." ${ }^{106}$ She notes two obstacles to establishing the right: first, the absence of a precise definition of the concept and content of the right, and second, the issue of its effective implementation. ${ }^{107}$

The report points out that there is no consensus on how to approach the definition and implementation of the right to the environment. One view holds that "new rights" that could be described as "ecological rights" should be defined. Another view advocates using the human rights recognized by existing international instruments as a basis for defining the "right to the environment. ${ }^{\prime \prime 108} \mathrm{Ksentini}$ reviews the various treaties and declarations which relate, often indirectly, to protecting the right to a clean environment. She also notes relevant provisions in several national constitutions. Her preliminary report very briefly mentions cases in the European Commission of Human Rights and the Human Rights Committee touching upon environmental issues. The special rapporteur concludes from the cases mentioned that an individual cannot yet claim a right to the environment directly, but can secure that right through the guarantees of traditionally recognized rights. ${ }^{109}$

105. U.N. Doc. E/CN.4/Sub.2/1991/8 (1991).

106. Id. at 29.

107. The report appears to contradict itself on the issue of whether an adequate framework for implementation is already in place. For example, in paragraph 76 the report states that "the recognition of [the right to the environment] has not yet led to the establishment of appropriate legal frameworks for its effective implementation." In paragraph 101, however, Ksentini reaches the conclusion that "there are enough frameworks for action in existence at the present time for [the right] to be effectively implemented." She adds that "although such implementation does not appear to be independently feasible for the time being, it is nevertheless possible." $1 d$. at $24,29$.

108. Id. at 22 .

109. For example, the European Commission of Human Rights declared inadmissible an application in which an individual sought to have the discharge of atomic waste in the North Sea declared a violation of the European Convention on Human Rights. In contrast, the Commission found that the "unbearable stress" suffered by an applicant living in a house situated between an airport and a motorway entitled her to claim a violation of Article 8 of the Convention (protection of private and family life). The Commission did not recognize the applicant's direct right to a peaceful environment but rather her right to be free of intrusions on her private and family life caused by environmental factors. Similarly, when the Human Rights Committee has encountered cases in which environmental matters affect human rights, it has based its decisions on rights guaranteed by the International Covenant on Civil and Political Rights. In the case of B. Ominayak and the 
Ksentini stresses the strong link between deterioration of the environment and violations of human rights. For example, the denial of the right of peoples to self-determination and sovereignty over their natural resources is a major cause of under-development and severe environmental damage. ${ }^{10}$ Denial of the right to participate in government decisions leads to development policies that fail to respond to people's needs or to preserve the environment. Violation of the right to information leaves people uninformed about environmental risks and hazards that directly affect them. ${ }^{11}$ Several NGOs also mentioned the human rights consequences of deforestation, chemical and nuclear accidents, and environmental destruction caused by the Persian Gulf War.

The Sub-Commission reiterated the recommendation of the Commission on Human Rights ${ }^{12}$ that Ksentini be invited to attend the United Nations Conference on Environment and Development (UNCED), which will be held in Brazil in 1992. ${ }^{113}$ The UNCED conference will probably produce an authoritative declaration on the environment and development. In her progress report expected for the 1992 Sub-Commission session Ksentini might consider how the substantial experience of the human rights community in devising methods of implementation and monitoring may be used to establish implementation mechanisms for the UNCED declaration.

\section{F. Administration of Justice}

The Sub-Commission considered several reports that fall under the broad heading of "administration of justice."114 Discussion took place both in the plenary sessions of the Sub-Commission and at meetings of the sessional Working Group on Detention, ${ }^{15}$ which are open to all members, government

Lubicon Lake Band v. Canada, the Committee found that historical inequities and certain recent developments, such as oil and gas prospecting, threatened the way of life and culture of the Lubicon Lake Band and violated Article 27 (minority rights) of the Covenant. ld. at 25 .

110. Id. at 19 .

111. Id. at 20 .

112. CHR Res. 1991/44, ESCOR, Supp. No.2, at 108, U.N. Doc. E/CN.4/1991/91 (1991).

113. Sub-Comm'n Res. 1991/24, 1991 Report, supra note 1, at 56.

114. Agenda item 10 is entitled, "The administration of justice and the human rights of detainees," and contains four sub-items: (a) question of human rights of persons subjected to any form of detention and imprisonment; (b) question of human rights and states of emergency; (c) individualization of prosecution and penalties, and repercussions of violations of human rights on families; and (d) the right to a fair trial. Agenda item 11 deals with the "independence and impartiality of the judiciary, jurors and assessors and the independence of lawyers."

115. In 1991 the working group members were Leandro Despouy (Argentina), Ribot Hatano (Japan), Aidid Abdillahi Ilkahanaf (Somalia), William Treat (United States), and Danilo Türk (Yugoslavia). 
observers, and NGOs accredited to attend the Sub-Commission session. The following reports were discussed at the 1991 session: the right to a fair trial; the independence and impartiality of the judiciary, jurors, and assessors, and the independence of lawyers; application of international standards concerning the human rights of detained juveniles; and states of emergency, including draft guidelines for the development of legislation on states of emergency. The Sub-Commission examined working papers on the privatization of prisons and on the practice of impunity for perpetrators of serious human rights violations. The Working Group on Detention considered a working paper on habeas corpus and discussed the death penalty, particularly as imposed on persons less than eighteen years of age; the working group asked El Hadji Guisse to present a working paper on the death penalty in 1992. In addition, Amnesty International informed the working group that it would no longer provide information for the Secretary-General's annual reports on detention because the reports omit the names of the specific countries involved. The Commission's new Working Group on Arbitrary Detention may supplant the Sub-Commission's Working Group on Detention in regard to cases and country situations.

The second report on the right to a fair trial, prepared by Stanislav Chernichenko (Soviet Union) and William Treat (United States), was wellreceived at the Sub-Commission. ${ }^{116}$ The report focused on interpretations of fair trial standards by the Human Rights Committee under the International Covenant on Civil and Political Rights, and covered aspects of arrest and detention, the right to release pending trial, the right to counsel, appeal, and remedies. The Sub-Commission requested the rapporteurs to identify aspects of the right to a fair trial which should be non-derogable. ${ }^{117}$ Members were particularly concerned about the right to habeas corpus. Having examined the very brief working paper on habeas corpus prepared by John Carey (alternate, United States), ${ }^{118}$ the Sub-Commission considered requesting a separate study on the topic, but instead asked Chernichenko and Treat to incorporate it into their study on the right to a fair trial. The Sub-Commission approved a three-year timetable for completing the study. Future reports will examine interpretations of fair trial standards of the European Commission and Court of Human Rights as well as the Inter-American Commission on and Court of Human Rights. The rapporteurs will also review national legislation and practice on the right to a fair trial. The Sub-Commission also asked the joint rapporteurs to consider the desirability of developing an international standard of basic fair trial guarantees, such as a model code. ${ }^{119}$

The Sub-Commission adopted a separate resolution underscoring the

116. U.N. Doc. E/CN.4/Sub.2/1991/29 (1991).

117. Sub-Comm'n Res. 1991/14, 1991 Report, supra note 1, at 43.

118. U.N. Doc. E/CN.4/Sub.2/1991NGG.1MP.1 (1991).

119. Sub-Comm'n Res. 1991/14, 1991 Report, supra note 1, at 43. 
importance of habeas corpus. ${ }^{120}$ The resolution called on all states that have not yet done so to establish a procedure such as habeas corpus so that a court may decide without delay on the lawfulness of a person's detention. The resolution also called on states to maintain the right to such a procedure "at all times and under all circumstances, including during states of emergency."

The fourth annual updated report on states of emergency ${ }^{121}$ took on special significance because of the attempted coup and declaration of a state of emergency in the Soviet Union, which occurred during the Sub-Commission session. The report by Special Rapporteur Leandro Despouy (Argentina) lists sixty-one countries which have proclaimed, extended, or terminated a state of emergency since 1 January 1985. Despouy followed his usual practice as special rapporteur of sending a note to the newly formed State Committee on the State of Emergency in the Soviet Union inquiring about the legal basis for the state of emergency and asking for a prompt reply. On the last day of the session, after the Soviet coup had failed, the Soviet government observer read its reply to the Sub-Commission that the state of emergency declared by the coup leaders had been illegal under Soviet and international law.

Despouy's report also contains draft guidelines for the development of legislation on states of emergency. The thirteen draft guidelines were prepared by Despouy and Louis Joinet (France) following a meeting of experts held in March 1991.'22 Despouy convened the meeting because of the complexity of the issue and the diversity of legal systems. The draft guidelines and accompanying commentary are at a very preliminary stage. In subsequent reports Despouy will refine the guidelines so that they can be used as a reference for governments seeking to reform their procedures on states of emergency. The Sub-Commission asked Despouy to continue to update his report and to complete work on his draft guidelines, with particular attention to be paid to the question of rights that are non-derogable during states of emergency. ${ }^{123}$

The Sub-Commission discussed Louis Joinet's report on the independence of the judiciary and the protection of practicing lawyers ${ }^{124}$ and asked him to submit another report in 1992. ${ }^{125}$ The report focuses on two areas: the UN advisory services and technical assistance program, including sem-

120. Sub-Comm'n Res. 1991/15, 1991 Report, supra note 1, at 43.

121. U.N. Doc. E/CN.4/Sub.2/1991/28 (1991).

122. The meeting of experts on the drafting of model legal provisions governing states of emergency was organized at the Palais des Nations in Geneva during March 1991 by the Association of International Consultants on Human Rights (CID). Id. at 28.

123. Sub-Comm'n Res. 1991/18, 1991 Report, supra note 1, at 48.

124. U.N. Doc. E/CN.4/Sub.2/1991/30 and Add.1-4 (1991). Thereinafter Independence of Judiciary].

125. Sub-Comm'n Res. 1991/35, 1991 Report, supra note 1, at 78. 
inars, training courses, and workshops; and specific measures and practices of states that strengthen or weaken the independence of the judiciary and the protection of lawyers. Joinet recommended that UN training programs develop more clearly defined objectives and that participants be chosen based on criteria of professionalism rather than politics - for example, that judges participate as judges and not as representatives of their governments. The special rapporteur also recommended that the Commission deny advisory services to any state that does not meet certain conditions, such as (1) minimal respect for human rights standards, and (2) the cooperation of the professionals for whom the advisory services are intended, rather than merely that of the government concerned. ${ }^{126}$ The recommendations reflect concern that some countries seek UN advisory services not out of a desire to strengthen the independence of their judges and lawyers but as a means to avoid closer scrutiny and condemnation of their own abuses in this area. Finally, Joinet asked that the Sub-Commission renew his mandate with respect to the second part of his report-measures and practices of states that strengthen or weaken the independence of the judiciary and legal profession - in order to obtain additional information from states. The Sub-Commission endorsed Joinet's recommendations and renewed his mandate for another year. ${ }^{127}$

Mary Concepcion Bautista (Philippines) presented a report on international standards concerning the human rights of detained juveniles. ${ }^{128}$ She also submitted a study prepared by the NGO Defence for Children International (DCl), which analyzes the application of such standards in fifteen countries. ${ }^{129}$ Bautista concludes that there has been a "progressive evolution" in the administration of juvenile justice but that serious deficiencies remain, including a widespread ignorance of international standards and a lack of financial resources. She also reiterates that rehabilitation should be the goal of juvenile justice. The Sub-Commission urged all governments to review their legislation and practices to ensure compatibility with international standards of juvenile justice. It also asked Bautista to submit an updated report in $1992 .^{130}$

The Sub-Commission considered working papers on the privatization of prisons by Miguel Alfonso Martinez (Cuba) ${ }^{131}$ and the practice of impunity for perpetrators of serious human rights violations by El Hadji Guisse (Senegal) and Louis Joinet (France). ${ }^{132}$ The Working Group on Detention asked Guisse to present a working paper on the death penalty in 1992. Martinez

126. Independence of Judiciary, supra note 124 , at 62 .

127. Sub-Comm'n Res. 1991/35, 1991 Report, supra note 1, at 78.

128. U.N. Doc. E/CN.4/Sub.2/1991/24 (1991).

129. U.N. Doc. E/CN.4/Sub.2/1991/50 (1991).

130. Sub-Comm'n Res. 1991/16, 1991 Report, supra note 1, at 44.

131. U.N. Doc. E/CN.4/Sub.2/1991/56 (1991).

132. U.N. Doc. E/CN.4/Sub.2/1991/WP.5 (1991). 
recommended that the Sub-Commission appoint a special rapporteur to examine privatization of prisons. Some Sub-Commission members asserted that prisons are by definition the responsibility of states and should not be privatized. The Sub-Commission decided to consider the issue again in 1992 and requested the Secretary-General to submit a working paper containing governments' views on the issue. ${ }^{133}$

The Sub-Commission asked Guisse and Joinet to proceed with a working paper on "measures to be taken to combat the increasingly widespread practice of impunity for perpetrators of serious violations of human rights." 134 Several NGOs, including Amnesty International and the International Commission of Jurists, highlighted the role of impunity in undermining respect for the law and preventing effective protection of human rights; they urged the Sub-Commission to undertake a study of the issue. Speakers stressed the need to uncover the truth about human rights violations in order to make any real progress in preventing future violations. Amnesty International pointed out that repressive governments often proclaim an amnesty just prior to relinquishing power, thereby forestalling investigation into their human rights abuses. In addition, successor governments often justify their amnesty laws by invoking the need for national reconciliation or security. The end result is that the perpetrators of human rights violations are not held accountable, which makes future violations more likely.

\section{G. Economic, Social, and Cultural Rights}

The second progress report by Danilo Türk (Yugoslavia) on economic, social, and cultural rights ${ }^{135}$ was widely discussed, even though it was scheduled for consideration during the busy final week of the Sub-Commission session. Some Sub-Commission members stated that the placement of this agenda item near the end of the session accurately reflected the low priority assigned to economic, social, and cultural rights compared to civil and political rights. Nevertheless, the comments during the Sub-Commission debate reflected the increasing attention paid to economic, social, and cultural rights by international bodies.

In introducing his report, Türk called development the "greatest drama of mankind." He noted that making progress in development requires technical knowledge as well as economic and political power. Türk indicated that events have revealed as myth the notion that centrally planned economies inevitably lead to the realization of economic, social, and cultural

133. Sub-Comm'n Dec. 1991/105, 1991 Report, supra note 1, at 84.

134. Sub-Comm'n Dec. 1991/110, 1991 Report, supra note 1, at 86.

135. U.N. Doc. E/CN.4/Sub.2/1991/17 (1991). 
rights; yet it is also a myth that a market economy automatically achieves this result.

Türk's report focuses on two issues that go to the heart of the current debate over development policies: first, the effects of structural adjustment policies on the realization of economic, social, and cultural rights; and second, the role of international financial institutions in this process. Türk concludes that the policies of the World Bank and the International Monetary Fund (IMF) have become more sensitive to their potentially devastating economic and social impact on the target population, but that far too often austerity measures result in a critical reduction of spending on basic health, education, birth planning services, and natural resource protection. Moreover, Türk finds little evidence that adjustment measures are successful in achieving growth. One key problem is the difficulty of measuring the precise social impacts of adjustment upon vulnerable groups, due to the absence of reliable indicators to measure the extent to which economic, social, and cultural rights are observed. ${ }^{136}$ Without reliable means of measurement, there is a great risk that such rights will continue to be overlooked when formulating structural adjustment policies. The Sub-Commission urged international and financial institutions to take greater account of the adverse impacts of their policies and asked Türk to submit a final report in 1992..$^{137}$

The report on human rights and extreme poverty ${ }^{138}$ outlined a method of work for a study that was authorized by the Commission in $1990 .{ }^{139}$ The Sub-Commission decided, however, to postpone consideration of the issue until 1992, and a draft resolution launching a study was withdrawn. ${ }^{140}$ In his report, Eduardo Suescun Monroy (alternate, Colombia) states that the first step in analyzing the interaction between human rights and extreme poverty is to study poverty itself: where it is found, how widespread it is, what forms it takes, and what causes it. Suescun identifies several causes of poverty, including underdevelopment, austerity measures imposed by the World Bank and IMF, lack of birth-control policies, discrimination against women, and widespread illiteracy. Suescun also recommends that the study focus on the 633 million people classified as "extremely" poor-the most difficult sector to reach but the essential starting point for any efforts to combat poverty. The Sub-Commission will examine Suescun's proposed

136. Türk submitted a separate working paper on indicators, which outlined principles and criteria to be considered at an upcoming expert seminar on economic and social indicators. U.N. Doc. E/CN.4/Sub.2/1991/WP.3 (1991).

137. Sub-Comm'n Res. 1991/27, 1991 Report, supra note 1, at 60.

138. U.N. Doc. E/CN.4/Sub.2/1991/18 (1991).

139. See CHR Res. 1990/15, ESCOR, Supp. No.2, at 47, U.N. Doc. E/CN.2/1990/94 (1990).

140. Some Sub-Commission members were reportedly concerned that a new study on extreme poverty would duplicate Türk's study on economic, social, and cultural rights. Many members also said that studies should be entrusted to members only, not alternates, which is Suescun's status. See Zoller, supra note 1 , at 8. 
method of work, which relies chiefly on input from the poorest themselves, at its 1992 session.

The Sub-Commission also discussed the human rights dimensions of population transfers, including the implantation of settlers and settlements. The working paper by Christy Ezim Mbonu (alternate, Nigeria) discusses the upheaval that accompanies migration and population resettlement schemes. ${ }^{141}$ She also points out that resettlement projects may have economic, strategic, or military objectives, and that such projects often improperly target indigenous peoples or ethnic or religious minorities in an effort to change the demographic composition of certain areas or to destroy a particular culture. The Sub-Commission noted the invariably serious consequences of population transfers and decided to consider the issue again in $1992 .{ }^{142}$

\section{H. Other Reports}

The Sub-Commission briefly discussed ongoing studies on compensation and rehabilitation for victims of gross violations of human rights, discrimination against HIV-infected persons and persons with AIDS, human rights and youth, and the protection of the rights of UN staff. The Sub-Commission postponed until 1992 its consideration of a working paper on the interrelationship between human rights and international peace. ${ }^{143}$ The Sub-Commission also appointed a sessional working group to draft a declaration of the right to leave and return, which made very little progress.

The Sub-Commission examined the progress report of Theo van Boven (Netherlands) on the right to restitution, compensation, and rehabilitation for victims of gross violations of human rights and fundamental freedoms. ${ }^{144}$ In delineating the scope of the study-defining who are the "victims" and what are the "gross violations" that will be compensated-the report reiterates that not only individuals but also "collectivities" may be entitled to compensation in certain cases. Van Boven also states that the "gross violations" which give rise to the right to restitution, compensation, or rehabilitation are those violations that entail grave injuries to human dignity, to a person's physical and moral integrity, or to the very existence of groups, communities, and peoples. The report specifically notes that gross violations of economic, social, and cultural rights, as well as systematic religious discrimination and intolerance, may also entitle victims to compensation in appropriate cases. Examples of such violations include a state's illegal oc-

141. U.N. Doc. E/CN.4/Sub.2/1991/47 (1991).

142. Sub-Comm'n Res. 1991/28, 1991 Report, supra note 1, at 62.

143. U.N. Doc. E/CN.4/Sub.2/1991/32 (1991).

144. U.N. Doc. E/CN.4/Sub.2/1991/7 (1991). 
cupation of a territory, violation of land rights by plundering natural resources, and environmental damage. The Sub-Commission asked van Boven to submit a second progress report next year and a final report in 1993. ${ }^{145}$

Discrimination against HIV-infected people or people with AIDS was the subject of a progress report by Luis Varela Quiros (former member, Costa Rica). ${ }^{146}$ The report surveys the many types of discrimination - for example, in housing, employment, medical care, and international travel-against persons infected with the HIV virus. It also stresses the paramount importance of education to combat AIDS-related discrimination, noting that laws against discrimination are positive but that lengthy litigation is not always a viable option for a person with a terminal illness. Varela concludes that experience has shown that the most successful AIDS programs espouse voluntary cooperation and confidentiality rather than coercive policies. The Sub-Commission asked the special rapporteur to submit a final report in 1992. ${ }^{147}$

During the discussion of the progress report on human rights and youth by Dumitru Mazilu (Romania), ${ }^{148}$ Sub-Commission members expressed both impatience at the slow progress of the report as well as understanding of the obstacles faced by Mazilu when he commenced his report several years ago. ${ }^{149}$ Members were disappointed at the rather narrow orientation of the report, which largely reflects Mazilu's personal experience in Romania. Although the Sub-Commission asked Mazilu to present another report next year, members stressed that the 1992 report must be the final report. The resolution specifically requested that Mazilu address problems of underdevelopment, unemployment, the right to conscientious objection to military service, and children in prison throughout the world. ${ }^{150}$

\section{PRE-SESSIONAL WORKING GROUPS}

The Sub-Commission has three working groups which meet prior to the start of every session. The Working Group on Indigenous Populations meets for two weeks and the Working Group on Contemporary Forms of Slavery for

145. Sub-Comm'n Res. 1991/25, 1991 Report, supra note 1, at 57.

146. U.N. Doc. E/CN.4/Sub.2/1991/10 (1991).

147. Sub-Comm'n Dec. 1991/109, 1991 Report, supra note 1, at 85.

148. U.N. Doc. E/CN.4/Sub.2/1991/42 (1991).

149. The Sub-Commission entrusted Mazilu with a report on human rights and youth in 1985. The report was originally to be presented in 1986, but the Sub-Commission session for that year was canceled. Mazilu was unable to present his report at the 1987 session because he had been placed under house arrest by the Ceausescu government in Romania and was not freed until the December 1989 revolution. See Brennan, Brody, \& Weissbrodt, supra note 1, at 298-300; Maher \& Weissbrodt, supra note 1, at 309-11; Brody, Convery, \& Weissbrodt, supra note 1 , at 280.

150. Sub-Comm'n Res. 1991/20, 1991 Report, supra note 1, at 52. 
one week immediately preceding the session. ${ }^{151}$ The Working Group on Communications meets in private sessions for two weeks prior to the SubCommission. It considers information about gross violations of human rights in specific countries and confidentially refers specific country situations to the Sub-Commission as a whole. ${ }^{152}$

\section{A. Working Group on Indigenous Populations}

The Working Group on Indigenous Populations met for its ninth annual session during the two weeks preceding the start of the Sub-Commission session. ${ }^{153}$ The working group's mandate is to review developments pertaining to the human rights of indigenous peoples and to prepare a Draft Declaration on the Rights of Indigenous Peoples. The session is an open forum: not only observer governments and NGOs in consultative status at the United Nations, but also any interested person or representative of an indigenous group, may attend. A voluntary fund established in 1985 promotes attendance by paying the travel and living expenses of some representatives of indigenous communities and organizations. Although the session in Geneva was very well-attended by indigenous peoples and organizations, the working group recommended that some of its future sessions be held in other regions, in particular Asia and Latin America, to increase local awareness of issues crucial to indigenous peoples. The working group pointed to the successful visits by its chairperson, Erica-Irene Daes (Greece), to Brazil and Japan during the previous year.

A major project of the working group for the past several years has been the drafting of a Declaration on the Rights of Indigenous Peoples. ${ }^{154}$ The working group will complete the draft in the next few years. The declaration is expected to deal with rights of indigenous peoples to self-determination; to collective and individual ownership of their land and water resources; to reclaim land and surface resources, or at least to seek just and fair compensation for resources which have been taken; to protection of their environment; to be consulted before large-scale projects are undertaken and to be compensated for adverse consequences of any projects undertaken;

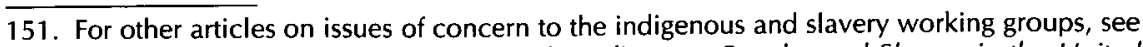
Human Rights Internet, For the Record-Indigenous Peoples and Slavery in the United Nations: A Special Report of Two Working Groups of the Human Rights Sub-Commission-August 1991 (1991).

152. The confidential, country-specific communications process is discussed in section II-L, supra.

153. Members of the 1991 working group were Erica-Irene Daes (Greece), Ribot Hatano (Japan), Miguel Alfonso Martinez (Cuba), Christy Ezim Mbonu (alternate, Nigeria), and Danilo Türk (Yugoslavia).

154. U.N. Doc. E/CN.4/Sub.2/1991/36 (1991). 
to be free from adverse discrimination; to be protected from genocide and ethnocide; to the protection of their lives and security of person; to maintain and develop their cultural identities; to practice their own religious traditions; to use their own languages; to teach their children in their own languages; to maintain and develop their traditional economic structures; to determine and implement health and other social programs affecting them; to participate fully in governmental decisionmaking about national and international matters; to determine the responsibilities of individuals to their own communities consistent with human rights norms; to maintain and develop contacts with other indigenous communities throughout the world; to have treaties and other agreements respected; and to mutually acceptable dispute resolution procedures.

Another study related to the working group is the study on treaties between states and indigenous peoples, ${ }^{155}$ which ECOSOC formally entrusted to Miguel Alfonso Martinez (Cuba) in 1989.156 The preliminary report due last year was postponed until the 1991 session, and some indigenous representatives were critical of the delays and lack of progress on the study. Martinez stressed the need for more time, money, and information; he hopes to complete the study in the next two to three years.

Other matters discussed during the working group session included working papers on the ownership and control of the cultural property of indigenous peoples, and on proposed activities for the 1993 "International Year of the World's Indigenous Peoples." The working paper on cultural property, prepared by Erica-Irene Daes (Greece), pointed out that indigenous peoples consider the restitution of cultural property-particularly the return of human remains, funerary objects, and sacred ceremonial and religious objects - essential to their enjoyment of human rights. ${ }^{157}$ The Sub-Commission asked Daes to prepare a study on ways to strengthen respect for cultural property of indigenous peoples to present to the Sub-commission in 1993. ${ }^{158}$

A working paper by Asbjorn Eide (Norway) and Christy Mbonu (alternate, Nigeria) outlines suggestions for activities to be held during the 1993 "International Year of the World's Indigenous Peoples."159 Despite the selection of 1993 as the UN year for indigenous peoples, many indigenous peoples appear to be paying more attention to 1992, which is the quincentennial of Columbus's arrival in the Western Hemisphere and which was initially proposed as the UN year. Nonetheless, the Sub-Commission welcomed the suggestions and recommended that the General Assembly designate a co-

155. U.N. Doc. E/CN.4/Sub.2/1991/33 (1991).

156. ECOSOC Res. 1989/77, at 154, U.N. Doc. E/1989/INF/7 (1989).

157. U.N. Doc. E/CN.4/Sub.2/1991/34, at 11 (1991).

158. Sub-Comm'n Res. 1991/32, 1991 Report, supra note 1, at 71.

159. U.N. Doc. E/CN.4/Sub.2/1991/39 (1991). 
ordinator for the International Year, that UN bodies hold meetings with representatives of indigenous groups to organize specific projects, and that indigenous persons be given preference when the UN obtains services and employs artists, consultants, and other professionals in connection with the International Year. ${ }^{160}$

\section{B. Working Group on Contemporary Forms of Slavery}

The Working Group on Contemporary Forms of Slavery held its sixteenth session for five days prior to the Sub-Commission session. ${ }^{161}$ The main theme of the session was "the prevention of traffic in persons and the exploitation of the prostitution of others." Participants discussed a broad range of issues, including the sexual exploitation of poor women and children, especially from developing countries; sex tourism; the sale of children; child labor; child soldiers; trafficking in organs from children; and debt bondage.

Working group members and observers lamented the low priority given such issues by governments, the Sub-Commission, and the Commission. They were particularly disappointed by the failure of Vitit Muntarbhorn (Thailand), the Commission's Special Rapporteur on Questions Relating to the Sale of Children, Child Prostitution, and Child Pornography, to attend the working group session. In its report to the Sub-Commission, the working group requested the special rapporteur to pay increased attention to trafficking in children, disappearances, the sale of children, child prostitution, and participation by children in armed conflicts; it also invited him to attend the 1992 session. ${ }^{162}$ Participants urged the working group to become more effective by developing practical proposals that governments can use to address the pressing issues of trafficking in persons and prostitution.

Two issues generated particularly lively discussion at the session: legalized prostitution in the Netherlands and reports of trafficking in organs from children. Advocates of abolishing prostitution criticized the Netherlands for attempting to distinguish between forced and voluntary prostitution; they rejected the Netherlands' approach of legalizing prostitution for adult women who "consent" to the prostitution. Participants called on governments to direct their punishment toward the procurers and customers of prostitutes and to develop programs to help women leave prostitution. NGOs called for a thorough investigation into the persistent reports of trafficking in organs from children. The working group noted that the still unverified information

160. Sub-Comm'n Res. 1991/33, 1991 Report, supra note 1, at 73.

161. The 1991 working group was composed of Ion Diaconu (Romania), Fatma Zohra Ksentini (Algeria), Claire Palley (United Kingdom), Waleed Sadi (alternate, Jordan), and Eduardo Suescun Monroy (alternate, Colombia).

162. U.N. Doc. E/CN.4/Sub.2/1991/41 (1991). 
about organ trafficking would have to be confirmed before any recommendations could be made. During the Sub-Commission debate on the working group's report William Treat (United States) pointed out that the technical constraints of organ matching and transplantation make it almost impossible to engage in the alleged illicit trafficking; he welcomed an investigation in order to put the rumors to rest once and for all. Asbjorn Eide (Norway) agreed that such trafficking would be technically very difficult and suggested that the World Health Organization would be in a better position than the SubCommission to handle the issue.

Several speakers expressed dissatisfaction with the large number of substantive reservations to the Convention on the Elimination of All Forms of Discrimination against Women (CEDAW). The working group agreed and prepared a draft resolution recommending that an advisory opinion be sought from the International Court of Justice regarding the validity of the reservations. ${ }^{163}$ The draft resolution was withdrawn, however, because some SubCommission members objected that it would be premature to act before consulting the CEDAW Committee and that an advisory opinion might turn out to be counter-productive. Some participants reasoned that certain countries, particularly Islamic countries, might choose to withdraw from the Convention entirely if forced to give up their reservations, with the possible result of even less compliance with international standards on discrimination against women.

The working group decided not to choose a main theme for discussion next year and, instead, will devote its session to an overall evaluation of its activities during the past three sessions. The Sub-Commission adopted a resolution requesting the UN Secretary-General to reassign to the working group a professional staff member from the Centre for Human Rights, as had been the case in the past, to work regularly with the working group. It also asked him to examine the possibility of holding the working group sessions in April or May to avoid overlapping with meetings of other working groups and thus to avert further burden on the staff of the Centre for Human Rights. ${ }^{164}$

\section{REFORM OF THE SUB-COMMISSION'S WORK}

The Sub-Commission pursued its work at the forty-third session against a backdrop of intense discussion of how to reform its method of work. The self-examination was prompted in large part by increased criticism from some members of the Commission on Human Rights. At the 1991 Commission session, at least nineteen states expressed views about the work of

163. U.N. Doc. E/CN.4/Sub.2/1991/L.49 (1991).

164. Sub-Comm'n Res. 1991/34, 1991 Report, supra note 1, at 75. 
the Sub-Commission. A common criticism was that the Sub-Commission duplicated the work of the Commission and spent too much time discussing human rights violations in specific countries. ${ }^{165}$ Various delegations suggested the following changes: a reduction in the number of studies; removal of country-specific discussions from the Sub-Commission's agenda; appointment of a commentator for each study to offer more comprehensive comments; a more even assignment of studies among Sub-Commission members, so that some members do not have more responsibilities than others; allocation of more time to studies on economic and social rights; adoption each year of a "global" report on human rights situations, rather than countryspecific resolutions (an idea opposed by many delegations); greater attention to "positive solutions" to human rights problems rather than criticism of these problems; a requirement that the Sub-Commission report to the Commission only every two years rather than every year; improved coordination between the Sub-Commission and Commission through intensive intersessional contacts between their bureaus; a prohibition on members of Commission delegations serving as experts of the Sub-Commission; a study of ways in which the Sub-Commission could function more effectively as a think tank of ideas and proposals; encouragement of NGOs and observer governments to limit their speeches to more relevant remarks; and better coordination with the UN Crime Branch in Vienna. ${ }^{166}$

The visit by Commission Chairman Enrique Bernales Ballesteros (Peru) to the 1991 Sub-Commission session underscored the importance of the reform issue. The previous session, in 1990, marked the first time that a Commission chairperson paid an official visit to the Sub-Commission. In 1991 Chairman Ballesteros delivered a speech in public session, followed by a two-hour private meeting with the twenty-six Sub-Commission members. Although the members welcomed the closer coordination between the Commission and Sub-Commission, there was no indication that members emerged with any sort of consensus on reforms which would effectively streamline the Sub-Commission's work. Indeed, although they acknowledged the need for reform, some Sub-Commission members pointed out that certain criticisms from Commission members seemed to ring hollow in light of the fact that the Commission itself continues to approve the resolutions and studies undertaken by the Sub-Commission.

Another indicator of the importance of the reform issue was the attention and controversy surrounding comments made by Morris Abram, the US ambassador to the United Nations in Geneva. Two weeks before the session began, an independent newsletter ${ }^{167}$ distributed at the United Nations in Geneva reported that Abram had suggested in a recent law review article

165. See Parker \& Weissbrodt, supra note 75 , at 607.

166. Id. at 607-08.

167. Sub-Commission must go, says US ambassador, 1 On The Record 1 (23 July 1991). 
and during a 17 July press conference that the Sub-Commission be abolished. In the article Abram charged that the Sub-Commission "spends most of its time examining country-specific human rights situations and generating studies and resolutions of marginal utility ... many of them reaching far beyond [its] mandate." ${ }^{168} \mathrm{He}$ further stated that the only apparent possibility for reform was for the Commission to " 'instruct' the Subcommission on the agenda and method of work to adopt." ${ }^{\prime 169}$ Although the next issue of the newsletter briefly noted that Abram was not actually proposing the complete abolition of the Sub-Commission, ${ }^{170}$ his comments both in the law review article and at the July press conference were widely discussed informally and were occasionally alluded to during Sub-Commission meetings.

Conscious of such criticisms, Sub-Commission Chairman Louis Joinet (France) announced at the outset of the session that reform was among the highest priorities of the 1991 Sub-Commission session. In his opening statement as chairman, Joinet focused not on the scope of the Sub-Commission's mandate but rather on its methods of work. He proposed that the 1991 session serve as a first step in a process of stage-by-stage structural reform. Joinet produced statistics from the 1990 session indicating how much time was lost due to failure to start meetings on time (one-and-a-half days) and showing the imbalance in speaking time among the twenty-six members (eleven days), eighty-two government observers (one day), and ninety-two NGOs (three days). ${ }^{171}$ Joinet also distributed to the members, in a private meeting, a document containing a precise breakdown of the amount of speaking time used by each member, observer government, and NGO. The figures revealed an extremely large range of total speaking time among individual members, with one member having spoken for a total of eightand-one-half hours, while others spoke for about one hour during the entire month-long Sub-Commission session.

In response to Joinet's presentation, the Sub-Commission announced guidelines to enable the Sub-Commission to stay on schedule. To ensure the timely start of meetings, the Sub-Commission authorized any Bureau member to open a meeting whenever the chairman was not present at the appointed hour. At least for the first two weeks the Sub-Commission met promptly at the time set for sessions. The Sub-Commission grew somewhat less punctual as the month progressed, but there was a significant improvement over previous years. As in earlier years, the Sub-Commission established limits on speaking time for government observers and NGOs and recommended limits for members. In 1991 the chairman was much more rigorous

\footnotetext{
168. Abram, Human Rights and the United Nations: Past as Prologue, 4 Harv. Hum. Rts. J.
70,80 (1991).
}

169. Id. at 81 .

170. Palais Pulse, 2 On The Record 12 (26 July 1991).

171. U.N. Doc. E/CN.4/Sub.2/1991MW.1 (1991). 
in reminding speakers of the time limits than in previous years. While the Sub-Commission members did not always observe the time limits, there was more self-discipline in 1991 than in earlier sessions.

Separate proposals for reform were submitted by Joinet, Ribot Hatano (Japan), and a group representing several NGOs. The proposals were considered by the sessional Working Group on Methods of Work. ${ }^{172}$ Hatano presented a draft set of rules of procedure that would radically alter SubCommission proceedings, ${ }^{173}$ but the Sub-Commission took no immediate action on them; members seemed to believe that some of Hatano's proposals would severely limit input from governments and NGOs and could be counter-productive to the Sub-Commission's work. The NGO group proposed, among other things, regrouping all agenda items under seven main headings and changing the order of speakers. ${ }^{174}$ It also cautioned against imposing severe restrictions on the rights of NGOs. Although the working group did not endorse any of the specific NGO proposals, it paid close attention to the NGO viewpoint, particularly regarding the need to reform the Sub-Commission in a manner that did not unduly restrict NGO participation.

Joinet made several proposals aimed at a higher quality of work and greater advance preparation in order to make the most efficient use of time during the session. His proposals included requiring a brief feasibility report before undertaking any new study or report; designating for each report one or more "commentators" whose task would be to draw attention to the main items to be discussed in the report; entrusting studies to alternate members of the Sub-Commission; requiring completion of a previous study before undertaking a new one; ensuring an equitable geographical assignment of reports among rapporteurs; updating past reports which merit a follow-up; more widely publicizing Sub-Commission reports; preparing annual lists of studies that have been completed or are still in progress; and expanding the practice of assigning two or three experts to prepare a report.

The Working Group on Methods of Work accepted in principle most of Joinet's proposals on improving the quality and efficiency of studies. ${ }^{175}$ In addition, the Sub-Commission began to implement one of the proposalsthe use of commentators - in regard to two studies, that is, on states of emergency and on the independence of the judiciary. Although the SubCommission responded partially to Joinet's ambitious proposals, its procedures require considerable reform. Indeed, on the last day of the session the

172. The working group consisted of Theo van Boven (Netherlands), Stanislav Chernichenko (Soviet Union), Fatma Zohra Ksentini (Algeria), Gilberto Vergre Saboia (Brazil), and Rajindar Sachar (India).

173. U.N. Doc. E/CN.4/Sub.2/1991MP.2 (1991).

174. U.N. Doc. E/CN.4/Sub.2/1991/NGO/21 (1991).

175. U.N. Doc. E/CN.4/Sub.2/1991/16 (1991). 
Sub-Commission was again subjected to severe criticism by US Ambassador Abram. Abram repeated his early charge that the Sub-Commission had "strayed from its original mandate" and stated that its "preoccupation with country situations usurps the role of other UN bodies." ${ }^{176} \mathrm{He}$ suggested that the Sub-Commission "put aside its less pressing studies and instead devote a week to reviewing the United Nations Human Rights implementation apparatus, and formulating recommendations to strengthen it."177 He pointedly noted that the Sub-Commission would have time to discuss its work if it would "return to its mandate and abide by the wishes of the U.N. Commission on Human Rights." 178

Abram's speech, as well as his earlier comments and law review article, drew substantial responses from Theo van Boven (Netherlands) and Asbjorn Eide (Norway), who traced the gradual expansion of the Sub-Commission's mandate and the increased work assigned to the Sub-Commission by its parent body. Van Boven disagreed with Abram's assertion that the reform of the Sub-Commission was simply a matter of adhering more closely to its original mandate. He stated that the Sub-Commission's methods of work undoubtedly need improvement, but he stressed that any reform of the SubCommission's work must take into account the Sub-Commission's place in the total UN human rights program as well as the scope of human rights issues today. The human rights landscape is qualitatively different from thirty years ago: governments are held more accountable; the rights of indigenous peoples have only recently been recognized; greater attention is paid to vulnerable groups such as women, children, migrant workers, refugees, and asylum-seekers; and human rights concerns are only now being integrated into economic and development matters. Van Boven emphasized that it would be wrong to attempt any reform without thoroughly analyzing how the Sub-Commission fits into this new landscape.

Other members also took issue with Abram's conclusions and other criticism of the Sub-Commission. Rajindar Sachar (India) pointed out that it is impossible to discuss human rights problems effectively without mentioning specific countries. He also saw the criticism as a concealed threat to cut off funds from the Sub-Commission. William Treat (United States) said that any criticism of the Sub-Commission should be constructive and that much criticism of the Sub-Commission was "sophomoric and unfair to SubCommission members individually and collectively." Everyone agreed, however, that the Sub-Commission needs significant reform and that its structural

176. Statement by Ambassador Morris B. Abram, US Permanent Representative to the United Nations in Geneva, on "Consideration of the Future Work of the Subcommission and of the Draft Provisional Agenda for the Forty-Fourth Session of the Subcommission" (30 Aug.

177. Id. 1991).

178. Id. 
problems should be the subject of attention at future Commission and SubCommission sessions.

\section{NEW INITIATIVES}

New initiatives at the Sub-Commission in 1991 included an unprecedented joint meeting on racial discrimination with another UN body; the adoption of resolutions concerning new aspects of economic, social, and cultural rights, such as forced evictions, the right to adequate housing, and fraudulent enrichment of government officials as an obstacle to the enjoyment of human rights; and brief discussions on two controversial issues: humanitarian intervention and the use of chemical-based weapons of mass destruction.

The Sub-Commission held a joint meeting with the Committee on the Elimination of All Forms of Racial Discrimination (CERD), the first joint meeting ever held by the Sub-Commission. For one-half day, members of the two bodies discussed issues of mutual concern in the field of racial discrimination and ways in which they might communicate information and coordinate their work. Members of the Sub-Commission and CERD will pursue the suggestions and decide what future action to take and whether additional meetings would be productive.

The Sub-Commission adopted resolutions for the first time on forced evictions, the right to adequate housing, and fraudulent enrichment of top government officials as an impediment to human rights. Sub-Commission members and observers noted the increasing use of involuntary, and sometimes violent, evictions in the name of urban renewal and development. The resolution noted that "forced evictions and homelessness intensify social conflict and inequality and almost invariably affect the poorest and the most socially, economically, ecologically and politically disadvantaged and vulnerable sectors of society, while promoting the interests of more powerful social groups."179 It further noted that often the actual motive behind forced evictions is discrimination based on race, ethnic origin, or other status. The resolution termed the practice of forced evictions a gross violation of human rights, which the Sub-Commission will examine more closely in 1992. A separate resolution requested Rajindar Sachar (India) to prepare a working paper on how to define and promote the right to adequate housing. ${ }^{180}$ The resolution noted that over one billion people do not enjoy adequate housing and that in many states the number of homeless and inadequately housed people is increasing. The resolution urged all states to pursue effective policies to guarantee the right to housing.

179. Sub-Comm'n Res. 1991/12, 1991 Report, supra note 1, at 39.

180. Sub-Comm'n Res. 1991/26, 1991 Report, supra note 1, at 58. 
The Sub-Commission resolution on fraudulent enrichment noted the devastating impact of the misappropriation of public funds on economic and social development. It called for "resolute political will" at the national level as well as international cooperation to combat such institutionalized corruption. The resolution specifically mentioned illicit arms trade, international drug trafficking, and money laundering as examples of corruption of a transnational character. It also stated that "developed countries have a special responsibility to contribute diligently to the restitution to despoiled peoples of the funds which their leaders have extorted from them."181

The issues of humanitarian intervention and chemical weapons generated debate among Sub-Commission members but did not result in any action being taken. Claire Palley (United Kingdom) brought up the two issues on the second day of the session. Palley proposed that the Sub-Commission launch a study on humanitarian intervention to examine under what conditions, and by whom, such intervention might be appropriate. Some members supported the concept in theory but stated that, in practice, intervention would likely be based on political rather than humanitarian considerations. Danilo Türk (Yugoslavia) noted that the military intervention envisaged in his own country was a response to concerns that were in essence political. ${ }^{182}$ Halima Embarek Warzazi (Morocco) asserted that there is no right to humanitarian intervention under international law, and that the recent experience of the Security Council authorizing intervention in Iraq demonstrated that, in practice, intervention is based on political considerations. She noted that the intervention was carried out for the benefit of one minority, the Kurds, but not others, such as the Shi' ites. Leandro Despouy (Argentina) took no position on whether the Sub-Commission should undertake a study, but noted that while the politically-charged notion of humanitarian intervention was being glorified by some parties, current violations of the right to asylum already an established international norm - were mostly greeted by silence. ${ }^{183}$ The member from Somalia, Aidid Abdillahi llkahanaf, wished that the international community had intervened in some manner when hundreds of thousands of people in his country were being exterminated and thousands more forced to take refuge in other countries. The Sub-Commission took no action on the proposal to study the issue of humanitarian intervention. ${ }^{184}$

181. Sub-Comm'n Res. 1991/36, 1991 Report, supra note 1, at 80.

182. Summary Record of the 4th Meeting, at 4, U.N. Doc. E/CN.4/Sub.2/1991/SR.4 (1991).

183. Id. at 9.

184. In December 1991 the UN General Assembly adopted a resolution that can be interpreted as a step toward establishing a right of humanitarian intervention by relief organizations. In response to criticism that its efforts to help Iraqi Kurds were ineffective, the United Nations decided to appoint a single humanitarian aid coordinator to deal with governments that deny assistance to suffering people. It is hoped that the new coordinator will work closely with the UN Secretary-General and the Security Council to put pressure on recalcitrant governments that deny aid to suffering people or use food or medicine as a 
A draft resolution on chemical weapons ${ }^{185}$ was discussed briefly, but the Sub-Commission decided by a vote of 11-4-5 to defer consideration of the issue until 1992. Some members stated that the topic should be handled in a forum other than the Sub-Commission because it was too far beyond the scope of human rights concerns. Other members were troubled because the resolution was amended to go beyond the types of weapons currently classified as "chemical weapons." For example, one amendment would have included such chemical-based weapons as napalm and fuel-air bombs, which were reportedly used by the United States in the Persian Gulf War and which are not considered "chemical weapons." Absent even basic agreement about whether the subject of chemical weapons is a human rights issue, the Sub-Commission deferred the matter until its 1992 session.

\section{CONCLUSIONS}

Some members of the Commission and particularly the US government have questioned the very existence of the Sub-Commission. As with earlier sessions, the Sub-Commission was faced with the problem of an overcrowded agenda in 1991. The chairman of the Sub-Commission made important proposals for procedural reform, but the Sub-Commission failed to accept several of the proposals.

While many aspects of the Sub-Commission's useful work continued and path-breaking resolutions were adopted on Tibet and forced evictions, the Sub-Commission has not fully responded to the challenge of the US government and of the Commission. Unless the Sub-Commission reforms its work, the challenge to its existence will grow or the Commission will impose major changes.

weapon to reward political supporters and punish opponents. During civil wars in Ethiopia, Iraq, Liberia, Sudan, and Somalia, governments as well as opposition groups used relief supplies as weapons. The UN resolution states that humanitarian assistance need no longer be given at the request of the concerned government but only with "the consent of the affected country." The step was viewed as a political victory for the United States and the European Community and met with hostility and skepticism from some third world governments, who claimed that the new rules would erode national sovereignty and encourage relief agencies to interfere in civil wars and other internal disputes. U.N. to Centralize its Humanitarian Relief Efforts, N.Y. Times, December 18, 1991, at A6, col. 4.

185. U.N. Doc. E/CN.4/Sub.2/1991/L.2, 1991 Report, supra note 1, at 98 (1991). 